\title{
THE EFFECTS OF ECONOMIC REFORMS ON MANUFACTURING DUALISM: EVIDENCE FROM INDIA
}

\author{
VINISH KATHURIA (vinish.kathuria@gmail.com) \\ SJMSOM, Indian Institute of Technology Bombay, Mumbai, India \\ RAJESH RAJ S.N
}

Centre for Multi-Disciplinary Development Research, Dharwad, India

KUNAL SEN

IDPM, University of Manchester, U.K.

FORTHCOMING IN JOURNAL OF COMPARATIVE ECONOMICS

[Acknowledgment: This paper forms part of a larger study funded by the Economic and Social Research Council (ESRC), United Kingdom. We are thankful to the ESRC for financial support. We are also thankful to the Central Statistical Organization for providing us access to the data and to Professor William Greene for many suggestions and comments. Earlier versions of this paper were presented at the Allied Social Science Associations Annual Meetings in Denver, USA (January 7-9, 2011), $9^{\text {th }}$ International Industrial Organization Conference in Boston, USA (April 8-10, 2011), $7^{\text {th }}$ Annual Conference on Economic Growth and Development, ISI New Delhi (December 15-17, 2011), $48^{\text {th }}$ The Indian Econometric Society Conference, Pondicherry (March 1-3, 2012) and a workshop in IIT Bombay (March 18-19, 2011). We thank the participants for their useful comments. We also thank the editor and the two anonymous for their helpful and extensive comments. The usual disclaimers apply.] 


\section{THE EFFECTS OF ECONOMIC REFORMS ON MANUFACTURING DUALISM: EVIDENCE FROM INDIA}

\section{Introduction}

Dualism is a pervasive feature of the manufacturing sectors of most developing economies. Typically the manufacturing sector in these economies has a large low-productivity informal sector, where most firms reside, along a relatively small high-productivity formal sector, comprising fewer firms (Little et al. 1987, Bourguignon and Morrisson 1998, Temple 2005, World Bank 2005). The informal sector comprises around two-thirds of non-agricultural employment and about a quarter of non-agricultural output in Africa and Asia ${ }^{1}$ (Charmes 2000, 2006), and in spite of strong economic growth in several African and Asian countries in recent years, the persistence in the size of the informal sector along with large differences in productivity and earnings between the informal and formal sectors has remained a matter of policy concern (ILO 2002, WTO 2009).

Persistence of manufacturing dualism has strong negative implications both for efficiency and equity in the economy (Mazumdar and Sarkar 2008). The existence of a large lowproductivity informal sector alongside the high-productivity formal sector can act as a constraint to the growth of aggregate productivity in the economy (Temple 2005). At the same time, sharp differences in earnings between workers in the informal and formal sectors lead to a high level of income and asset inequality, which may worsen further if the process of economic growth is biased towards the growth of the formal sector (in terms of productivity and capital accumulation) rather than the informal sector (WTO 2009).

While the determinants of the persistence of manufacturing dualism is not well understood, it is commonly believed that an important factor behind the prevalence of dualism is the policy regime, and that trade and industrial policies that inhibit competition and technological change may exacerbate dualism, especially if they are protective of the formal sector or constrain the growth of the informal sector (Little 1987, Gang 1992, Tybout 2000). Economic reforms that allow for a level playing field between the informal and formal sectors may therefore act as a significant positive force in reducing dualism (World Bank 2005). However, it is not clear if this will indeed be the case if economic reforms provide a more favourable environment for the more well-resourced larger firms in the formal sector to expand and reap economies of scale, to obtain best-practice technology, and to seek market 
opportunities overseas as compared to less well resourced smaller firms in the informal sector. Therefore, whether economic reforms help reduce manufacturing dualism or exacerbate it is an empirical question.

In this paper, we examine the effects of economic reforms on manufacturing dualism, which we take to mean the existence of productivity differentials between informal and formal manufacturing firms. We are specifically interested in the technical efficiency levels of formal and informal manufacturing firms and the effects of economic reforms on these efficiency levels. We measure efficiency using the stochastic frontier analysis (SFA) method pioneered by Aigner et al. (1977). Technical efficiency captures the extent to which firms in the manufacturing sector are producing the maximum possible output, for a given bundle of inputs, in a given industry, and improvements in technical efficiency of the average firm imply a higher level of output being produced on average, for a given level of inputs in that industry (Kumbhakar and Lovell 2000).

The country we study is India, where there is a long history of manufacturing dualism (Little et al. 1987) and where about 80 per cent of manufacturing employment and 17 per cent of manufacturing output is in the informal sector (NCEUS 2007). It is commonly believed that the dualism evident in the manufacturing sector was a legacy of a set of economic policies that provided protection to the larger manufacturing firms from external competition via an import substituting industrialization policy regime and also made it difficult for new firms, whether domestic or foreign, to enter the formal sectors of industries through a strict licensing policy (Panagariya 2008). At the same time, small firms (which were mostly in the informal sector) were protected via a small scale sector reservation policy which did not allow larger firms to produce specific products that were seen as the domain of small firms (Mohan 2002). This led to an industrial structure where both very small and very large firms were present in the same industry, with significant productivity differences between the informal and formal sectors (Kochhar et al. 2006, Mazumdar and Sarkar 2008). In the early 1990s, with the advent of major economic reforms, industrial licensing was abolished in majority of industries, followed by a second wave of de-licensing in the mid 1990s. India has also witnessed rapid trade liberalisation since 1991, where there was a significant reduction in tariffs on most commodities (Sen 2008). The trade reforms were particularly targeted to the manufacturing sector which was among the most protected in the developing world prior to the 1990s (Bhagwati and Srinivasan 1975). The reservation of industries for the small sector 
was also gradually phased out since the mid 1990s. These reforms were mainly in product markets and varied substantially over time and across industries. Thus, they provide us a unique empirical context to evaluate the effects of economic reforms on efficiency differentials between informal and formal firms. Existing studies do not provide an unambiguous answer on the impact of these reforms on efficiency of formal and informal manufacturing firms, and whether there has been a widening or narrowing increasing efficiency gap between the more efficient formal firms and the less efficient informal firms following these reforms (Kathuria et al. 2010). ${ }^{2}$ We construct a composite reform variable that captures the key sets of product market reforms enacted in India since the late 1980s, which are de-licensing, de-reservation and tariff reforms, and test for its effect on efficiency differentials between formal and informal firms, as well as examining the effects of each of the product market reforms on these differentials separately.

We use a very rich data-set which combines large representative surveys of informal firms with the census-cum-sample data on formal manufacturing firms. The data are pooled crosssections of firm-level data, available quinquennially, beginning in 1989-90 and ending in 2005-06.We employ stochastic frontier analysis to obtain firm level measures of technical efficiency. Since the location of the firm, especially around the threshold size, either in the formal or in the informal sector is not random but depends on firm choice, a comparison of efficiency levels between firms in the informal and formal manufacturing sectors without addressing the endogeneity of firm location would not be appropriate. Such a comparison would bias upwards the efficiency levels of formal manufacturing firms if these levels depended on the firm being located in the formal sector. Our stochastic frontier analysis corrects for this selection bias, using a methodology proposed by Greene (2010). We find strong evidence that economic reforms have helped the productivity of Indian manufacturing firms to increase across both the formal and informal sectors, the increase being more for the formal sector firms. Economic reforms have caused an increase in manufacturing dualism in India by increasing efficiency differentials between formal and informal firms.

The rest of the paper is in five sections. In the next section, we provide a brief discussion of the Indian policy regime pertaining to the manufacturing sector and how these reforms may have affected the efficiency levels of formal and informal firms. In Section III, we describe our econometric methodology and discuss the empirical specification. Section IV describes 
the data and the variables used in the empirical analysis. Section V presents the results of the empirical analysis. Section VI concludes.

\section{Policy Reforms in Indian Manufacturing}

The formal manufacturing sector in India is taken to be definitionally equivalent to the organized sector, which comprises firms which are registered under the Factories Act of 1948 of the Government of India (Kulshreshtha 2011). Firms have to register with the Indian government under the Factories Act if they employ ten or more workers and use electricity in their operations, or if they employ twenty or more workers without the use of electricity in their operations (Pais 2008). The Factories Act regulates the conditions of work in the formal manufacturing sector, including minimum safety, sanitary, health and welfare standards, as well as stipulating regulations on hours of work, leave with wages and holiday provisions for workers which employers in the formal sector need to follow or face stiff penalties (NCEUS 2009). In addition, firms registered under the Factories Act are required to supply data on the firm's operations on a regular basis to the official Indian statistical agency, the Central Statistical Organisation (Kulshreshtha 2011). The informal manufacturing sector, by default, comprises firms which fall outside the scope of the Factories Act; they generally do not pay taxes and are outside the purview of government regulations (Kanbur 2011).

Registration under the Factories Act implies that the firm will have to comply with a wide range of government regulations that are exclusively applicable to the formal sector. However, it also implies that the firm will be able to access credit from the formal financial sector, including loans from specialized development financial institutions and commercial banks. Among the most onerous government regulations that firms in the formal manufacturing sector in India face are employment protection legislation which is among the most restrictive in the world (Ahsan and Pages 2009, Dougherty 2008). In addition, all firms in the formal sector, irrespective of size, are subject to environmental regulations and minimum wage legislation, which informal sector firms are not.

The most important set of policies that the Indian government has followed with respect to the manufacturing sector was a comprehensive industrial licensing system (more commonly known as the License Raj in the literature, see Mookherjee (1995)).For first four decades since independence, the government intervened in almost all aspects of the activities of formal manufacturing firms. Industry in India was subject to rather formidable legal barriers to entry. Investments, both in terms of expansion of capacity of existing firms and creation of 
new firms, was controlled by the government through its licensing policies that were in turn determined according to plan priorities. Though the purported objective of the licensing regime was balanced growth, it effectively led to a more monopolistic structure and significantly encouraged rent-seeking by corporations entrenched with public powers (Aghion et al. 2008). Following an initial attempt in 1975-76, the liberalisation of industrial controls gathered momentum in 1985-86 when some industries and small sized firms were taken out of the purview of industrial licensing and modernisation of equipment along with expansion of capacity were also allowed in a limited manner (Mookherjee 1995). In 1991, the License Raj effectively came to an end, when industrial licensing was abolished irrespective of the level of investment except for sixteen core industries. The number of industries reserved for the public sector was significantly reduced. Also, under the new policy guidelines on foreign investment, automatic permission is granted for foreign equity participation up to 51 per cent in a specified list of high technology and high investment priority industries.

In addition to the industrial licensing system, the Indian government followed a trade regime since independence which was aimed at the comprehensive, direct control over foreign exchange utilisation, with an overwhelming reliance on quotas rather than tariffs (Bhagwati and Srinivasan 1975). The trade regime provided a significant degree of protection to firms in Indian manufacturing. Nearly all imports were subject to discretionary import licensing or were "canalised" by government monopoly trading organisations. Beginning with the exportimport policy of 1977-78, there was a slow but sustained relaxation of import controls. The pace of the trade reforms - in particular, the shift from quantitative import controls to a protective system based on tariffs - initiated in the mid-seventies were considerably quickened in the second half of the 1980s. Restrictions on the import of capital goods were further eased to encourage technological modernisation. In 1991, as a part of the comprehensive economic reform programme initiated that year, there was a significant liberalization of the trade regime with respect to capital goods. Import licensing was virtually abolished with respect to the imports of most machinery and equipment and manufactured intermediate goods (Sen 2008). There was also a significant cut in tariff rates, with the peak tariff rate reduced from 300 per cent to 150 per cent and the peak duty on capital goods cut to 80 per cent. Import-weighted average tariff rates fell from an average of 83 per cent in 1990 to 29 per cent in 1995-96 (Alessandrini et al. 2011). 
While the industrial licensing and trade policies were mostly targeted to the formal manufacturing, the reservation policy for the small-scale sector which initiated in 1967 mostly applied to the informal sector. Under this policy, selected products were identified for exclusive production by the small-scale sector. ${ }^{3}$ The products chosen for reservation by the government were very diverse, and covered industries such as food, chemicals, electronics and textiles. The initial list of products reserved for the small-scale sector was 47 but this increased to 836 by 1989 (Mohan 2002). Entry into the products reserved for the small scale sector was not allowed for large firms and by foreign investors. While the small-sector reservation policy was designed to protect small firms, it also did not allow these firms to grow, to invest in quality upgrading and to benefit from foreign direct investment (Mohan 2002, Mazumdar and Sarkar 2008). Starting in 1997, products were gradually removed from the reservation list and by 2010 only 21 products remained in this list.

\section{Expected Effect of Product Market Reforms on Efficiency Differentials between Formal and} Informal Firms

Industrial de-licensing, trade reforms and de-reservation were the key product market reforms enacted by the Indian government with respect to the manufacturing sector. ${ }^{4}$ The impact of these product market reforms may be different on formal versus informal firms. Consider first the de-licensing reforms of the mid-1980s and early 1990s that largely pertained to the formal manufacturing sector. With the withdrawal of restrictions on firm expansion and new firm entry, formal firms would be expected to increase in size and reap economies of scale. In addition, new firm entry is likely to bring about an increase in average efficiency of formal firms in a given industry, both by exerting competitive pressures on incumbent firms and via the introduction of more productive new firms into the industry (Taymaz 2005). ${ }^{5}$ The licensing reforms are also expected to stimulate many dynamic small and medium enterprises which have been unnecessarily hampered by the licensing system (Government of India 1991). At the same time, informal firms may have benefited indirectly from the license reforms as expanding formal firms entered into sub-contracting arrangements with informal firms for supply of inputs, and invested in the technological capabilities of informal firms so as to obtain reliable and high quality specialized intermediate and capital goods (Schmitz 1982, Yang and Chen 2009, Kotwal et al. 2011).

Similarly, trade reforms in the form of reduced tariffs would have had a pro-competitive effect on those firms that are in direct competition with imports, these firms being mostly in 
the formal sector (Tybout 2000). Since informal firms primarily cater to the local market, and do not compete directly with imports, the efficiency enhancing effects of trade reforms would be less for these firms. On the other hand, informal firms would be better able to adjust their use of labour and capital in response to trade reforms as compared to formal firms who face various policy induced impediments to the adjustment of factors of production. Besides, there can also be an indirect impact on informal firms if they are working as subcontractors for formal firms. Thus, it is not clear that trade and de-licensing reforms would necessarily increase efficiency levels in formal firms more than in informal firms.

With respect to the de-reservation of products for the small scale sector, it would be expected that these reforms would benefit informal firms as these firms would not face disincentives to expand the scale of production that existed under the reservation policy (since the size limits that applied under this policy penalized the expansion of firms). Efficiency levels of informal firms may also increase via the greater competition that these firms will face from formal firms entering into product markets that were reserved for small firms. At the same time, the ability of formal firms to move into these product markets may provide efficiency gains to these firms as they obtain both economies of scale and scope in production. Here again, the effect of de-reservation on efficiency differentials between formal and informal firms is theoretically ambiguous.

We empirically investigate in this paper whether the product market reforms enacted since the mid-1980s have led to an increase in efficiency of formal firms relative to informal firms. But first we set out our econometric methodology below.

\section{Econometric Methodology and Empirical Specification}

We use stochastic frontier analysis (SFA) to estimate firm efficiency. ${ }^{6}$ We are interested in determining the technical efficiency of the firm - the maximum possible output that a firm can produce, given its inputs. The standard approach to SFA does not account for selection bias and therefore, the comparison of efficiency levels of formal and informal firms without addressing the endogeneity of firm location may yield biased results.

We employ a method proposed by Greene (2006) that incorporates 'sample selection' into a stochastic frontier framework. ${ }^{7}$ He proposes the following analytical approach:

$$
\begin{aligned}
& d^{*}=\alpha^{\prime} z+w, \quad d=1, d^{*}>0 \\
& y=\beta^{\prime} x+v-u
\end{aligned}
$$


$u=|U|, \quad$ with $U \sim N\left[0, \sigma_{u}^{2}\right]$

$(v, w) \sim$ bivariate normal with $\left[(0,0),\left(\sigma_{u}^{2}, \rho \sigma_{v}, 1\right)\right]$

$(y, x)$ only observed when $d=1$

where $\mathrm{d}$ is a probit selection equation (with its adoption depending on a host of price and non-price factors) and $\mathrm{y}$ is the stochastic frontier function, specified only for the adopting firms. In the present case, the selection is whether to formalize or continue working in informal sector based on several institutional factors. We then estimate a stochastic frontier function for only those firms, which decide to be in the formal sector. ${ }^{8}$

The estimation, thus, is divided into two parts. For the selected observations, $d=1$, conditioned on $\mathrm{v}$, the joint density for $\mathrm{y}$ and $\mathrm{d}$ is the products of the marginals as conditioned on $\mathrm{v}$, where $\mathrm{y}$ and $\mathrm{d}$ are independent.

$f(y, d=1 \mid x, z, v)=f(y \mid x, v) \operatorname{prob}(d=1 \mid z, v)$

This is the second part. For the first part,

$y \mid x, v=\left(\beta^{\prime} x+\sigma_{v} v\right)-\sigma_{u} u$

where $\mathrm{u}$ is the truncation at zero of a standard normal variable, as is done in estimating stochastic production frontier.

Therefore, the joint conditional density is given by:

$f(y, d=1 \mid x, z, v)=\frac{2}{\sigma_{u}} \emptyset\left(\frac{\left(\beta^{\prime} x+\sigma_{v} v\right)-y}{\sigma_{u}}\right) \varphi\left(\frac{\alpha^{\prime} z+\rho v}{\sqrt{1-\sigma^{2}}}\right)$

We obtain the unconditional density by integrating $\mathrm{v}$ out of equation (3). The integral does not exist in a closed form and hence, Greene (2006) proposes computation by simulation. The final simulated log likelihood is given by:

$\log L_{s}=\sum_{i} \log \frac{1}{R} \sum_{r=1}^{R}\left\{d_{i}\left[\frac{2}{\sigma_{u}} \emptyset\left(\frac{\beta^{\prime} x+\sigma_{v} v_{i r}-y}{\sigma_{u}}\right) \varphi\left(\frac{\alpha^{\prime} z+\rho v_{i r}}{\sqrt{1-\sigma^{2}}}\right)\right]+\left(1-d_{i}\right)\left[\varphi\left(\frac{-\alpha^{\prime} z+\rho v_{i r}}{\sqrt{1-\sigma^{2}}}\right)\right]\right\}$

The model is estimated using NLOGIT version 4.

\section{Empirical Specification}

Our empirical strategy involves three stages: in the first stage, we estimate a probit equation which models the selection of firms into the informal and formal sectors, and in the second stage, estimates for the production function and for technical efficiency are obtained, 
conditioned on the sample selection. Once we obtain the efficiency estimates, in the third stage of the analysis, we carry out regressions to see the impact of reforms on efficiency differentials between the formal and informal sector.

\section{First Stage Analysis}

We assume that firms can choose between being in the formal or informal sector subject to a set of variables that capture the benefits and costs of formalization. The decision of the $i^{\text {th }}$ firm to be in the formal sector is described by an unobservable selection criterion function, $\mathrm{F}^{*}$, that is postulated to be a function of variables that determine the benefits and costs of formalization. The model is specified as:

$$
\mathrm{F}^{*}=\alpha \mathrm{Z}_{\mathrm{i}}+\mathrm{w}_{\mathrm{i}}
$$

Where $\mathrm{Z}$ is a vector of variables explaining the decision to formalize, $\alpha$ is a vector of parameters, and $\mathrm{w}_{\mathrm{i}}$ is the white noise error term.

The selection criterion $\mathrm{F}^{*}$ is not observed. Instead, a dummy variable $\mathrm{F}$ is observed which takes the value of one for formal sector firms, and zero for informal sector firms.

Therefore, $\mathrm{F}=1$, if $\mathrm{F}^{*}=\alpha \mathrm{Z}_{\mathrm{i}}+\mathrm{w}_{\mathrm{i}} \geq 0$; and $\mathrm{F}=0$, otherwise

To obtain the set of explanatory variables which determine the benefits and costs of formalization, we draw from recent theoretical literature on why firms formalize. We also exploit the fact that there are important differences in institutions relating to labour regulation, access to credit and the provision of infrastructure across Indian states and over time. A key factor that has been highlighted by both the theoretical and empirical literature is the degree of regulation faced by the firm if it chooses to be in the formal sector (Fajnzylber et al. 2011, Ulyssea 2010, Taymaz 2009, Dabla-Norris et al. 2005). While the regulatory framework relating to product market entry and exit are the same across states in India, labour regulations have differed greatly across Indian states. Industrial relations in India fall under the joint jurisdiction of the central and state governments. A particular piece of labour legislation that has particularly detrimental to the growth of the formal manufacturing sector in India, and has encouraged informality, is the Industrial Disputes Act (IDA) of 1947, which sets out the conciliation, arbitration and adjudication procedures to be followed in the case of an industrial dispute. The IDA applies only to formal sector firms and imposes significant restrictions on employers regarding layoff, retrenchment and closure. Since labour laws are 
both within the jurisdiction of state and central governments, the IDA has been extensively amended by state governments during the post-independence period. We would expect that more pro-employer labour law amendments (LABOUR LAWS)as seen by a higher value of our variable would have a positive effect on the firm's decision to formalize.

A second factor highlighted by the theoretical literature is access to formal sector credit (Straub 2005). The higher the likelihood for a firm to obtain formal sector credit, which are usually on more favourable terms than informal sector credit and at lower interest rates, the more likely that the firm will choose to be in the formal sector. This is because registration as a formal sector unit is often a precondition for firms to access credit from specialized formal sources such as commercial banks and development finance institutions. In India, government regulations made it mandatory for commercial banks to lend a large proportion of their funds to small and medium enterprises in the formal manufacturing sector (which are mostly the units that are making the transition from the informal sector) along with farmerhouseholds in the agricultural sector - these regulations were called priority sector lending requirements (Sen and Vaidya 1997). Access to priority sector lending depended a great deal on the level of financial development in a given state, and this differed from state to state and across time (Burgess and Pande 2005). We capture differential access to formal sector credit for small and medium enterprises across Indian states and over time by the share of bank lending going to priority sectors (PRIORITY SECTOR LENDING).

Our third variable to explain the decision of a firm to formalize is the provision of a productive public good to formal sector firms which creates a strong incentive to formalize (Dessy and Pallage 2003). We take the public good to be electricity, which has been found to be a binding constraint for formal manufacturing growth in India (World Bank 2004). Indian states have differed widely in their ability to provide electricity to manufacturing firms, in part due to the very different performance of State Electricity Boards, the main agency responsible for transmission and distribution, across Indian states (Krueger and Chinoy 2002, Panagariya 2008). Following Bond and Malik (2007), we measure the electricity constraint on a firm's decision to formalise by the transmission and distribution losses of electricity as percentage of total energy availability at the state level ( $T \& D L O S S E S)$. The power transmission and distribution losses are a suitable proxy for electricity infrastructure because the higher the losses in a given state, the higher the probability that firms will have 
operational problems with electricity, and the greater the disincentive for firms to move from the informal to the formal sector to take advantage of access to electricity in the state. ${ }^{9}$

We estimate probit model of the following type:

$F=f(L A B O U R$ LAWS, PRIORITY SECTOR LENDING, T\&D LOSSES)

where $\mathrm{F}$ is 1 if the firm is in the formal sector, 0 otherwise. We expect that the signs of LABOUR LAWS and PRIORITY SECTOR LENDING will be positive while the sign of $T \& D$ LOSSES will be negative.

We estimate the probit equation for each industry separately, but for all four years combined. ${ }^{10} \mathrm{We}$ explain below why we estimate the probit model separately for each industry.

\section{Second Stage Analysis}

The production behaviour of formal and informal sector firms is modeled using a simple Cobb Douglas function. Thus, we have:

$$
\ln \left(\mathrm{Y}_{\mathrm{iT}}\right)=\beta_{0}+\beta_{1} \ln \left(\mathrm{K}_{\mathrm{iT}}\right)+\beta_{2} \ln \left(\mathrm{L}_{\mathrm{iT}}\right)+\left(\mathrm{v}_{\mathrm{iT}}-\mathrm{u}_{\mathrm{iT}}\right)
$$

Where T=1989-90, 1994-95, 2000-01 and 2005-06 and $\mathrm{i}$ is the firm. $\mathrm{Y}$ is gross value added, $\mathrm{K}$ is capital stock, $\mathrm{L}$ is labour, and $\beta \mathrm{s}$ are the parameters to be estimated. The $\mathrm{v}_{\mathrm{iT}} \mathrm{s}$ are random variables independent of the $\mathrm{u}_{\mathrm{iT}} \mathrm{S}$ and purport to capture the random shocks that are beyond the control of firms. The $\mathrm{u}_{\mathrm{iT}} \mathrm{S}$ capture technical inefficiency and are the combined outcome of non-price and organizational factors that constrains a firm from achieving their maximum possible output from the given set of inputs and technology. The $u_{i} s$ are non-negative and assumed to be identically distributed at truncations at zero, $\mathrm{u}=|\mathrm{U}|$ with $\mathrm{U} \sim \mathrm{N}\left[0, \sigma_{\mathrm{u}}^{2}\right]$. Technical efficiency $\left(\mathrm{TE}_{\mathrm{i}}\right)$ is measured as the ratio of the observed output $\left(\mathrm{y}_{\mathrm{i}}\right)$ of the firm to the potential output $(\hat{\mathrm{y}})$ derived by the frontier function, $\mathrm{TE}_{\mathrm{i}, \mathrm{t}}=\mathrm{y}_{\mathrm{i}, \mathrm{t}} / \hat{\mathrm{y}}_{\mathrm{t}}$, where $\mathrm{TE}_{\mathrm{i}, \mathrm{t}}$ is technical efficiency for firm $\mathrm{i}$ in year $\mathrm{t}$.

Instead of estimating the same production function for the entire set of firms, irrespective of industry, we estimate equation (7) industry by industry and for each of the two groups formal and informal separately, at the National Industrial Classification (NIC) 2 digit industry level (broadly corresponding to the ISIC 3 digit level of industrial classification used by the United Nations Industrial Development Organization). There are twenty-two industries in our data-set (we provide the list of industries along with the industry codes in Appendix Table 
A1). By estimating the production function separately for formal and informal firms at the industry level, we not only allow the parameters for capital and labour in the firm-level production function to differ across industries but also across the two groups. This is a reasonable assumption to make when a) the industries differ so widely in their production technology and in characteristics relating to export orientation and market structure (e.g., leather versus electrical machinery); and b) even within the same industry, production coefficients may be different for labour-intensive informal firms and capital-intensive formal firms.

\section{Third Stage Analysis: Impact of Reforms on Technical Efficiency}

In this stage, we regress firm-specific technical efficiency on a composite measure of reforms (REFORM) and a variable representing firm location (FORMAL). As discussed in Section II, the major product market reforms that have occurred in the Indian economy since the mid1980swere the withdrawal of the requirement of a license that firms require if they wish to produce in a given industry (DELICENSE), the de-reservation of products earlier earmarked only for small scale and informal producers (DERESERVE) and trade reforms in the form of cuts in import tariffs (TARIFF). The Composite measure is a weighted index of these three reforms and is given by:

$\operatorname{REFORM}_{\mathrm{jt}}={ }_{\mathrm{i}=1} \Sigma^{3} \mathrm{w}_{\mathrm{i}}$ Reform $_{\mathrm{ijt}}$

where $\mathrm{w}_{\mathrm{i}}$ is the weight for each of the product market reform variables. We assume equal weights for each of the three product market reform variables (that is $\mathrm{w}_{\mathrm{i}}=0.33$ ).

To estimate the effect of economic reforms and firm location in the formal sector on technical efficiency, we use the following specification:

$$
T E_{\mathrm{ijt}}=\alpha+\beta_{1} \mathrm{FORMAL}_{\mathrm{ijt}}+\beta_{2} \mathrm{REFORM}_{\mathrm{jt}}+\delta_{\mathrm{j}}+\gamma_{\mathrm{t}}+\varepsilon_{\mathrm{ijt}}
$$

Where $T E_{\mathrm{ijt}}$ is technical efficiency of firm $\mathrm{i}$ in industry $\mathrm{j}$ and year $\mathrm{t}$ and FORMAL is a dummy for firm location which takes the value one if the firm is in the formal sector, and zero if the firm is in the informal sector. $\delta_{\mathrm{j}}$ are industry fixed effects, $\gamma_{\mathrm{t}}$ are year effects and $\varepsilon_{\mathrm{ijt}}$ is the error term. If $\beta_{2}$ is greater than zero (and statistically significant), this would imply that product market reforms have facilitated firms to increase their efficiency. Similarly, if $\beta_{1}$ is greater than zero and statistically significant, we would conclude that formal firms are more efficient than informal firms and vice versa if $\beta_{1}$ is less than zero. 
To examine the differential impact of reforms on informal and formal firms, we introduce an interaction term, FORMAL*REFORM, where we interact our reform variable (REFORM) with the FORMAL variable. Thus, the revised model estimated is as follows:

$$
T E_{\mathrm{ijt}}=\alpha+\beta_{1} \text { FORMAL }_{\mathrm{ijt}}+\beta_{2} \text { REFORM }_{\mathrm{jt}}+\beta_{3} \text { FORMAL }^{*} \text { REFORM }_{\mathrm{ijt}}+\delta_{\mathrm{j}}+\gamma_{\mathrm{t}}+\varepsilon_{\mathrm{ijt}}
$$

The coefficient $\beta_{3}$ measures the differential impact of reforms on formal and informal firms. A positive and statistically significant $\beta_{3}$ (along with a positive and statistically significant $\beta_{2}$ ) implies that reforms have led to a greater increase in the efficiency of formal firms as compared to informal firms indicating exacerbation of dualism in Indian manufacturing sector. A negative and statistically significant $\beta_{3}$ would imply just the reverse.

It should be noted that in equation (9), the effect of FORMAL on technical efficiency is given by the expression, $\beta_{1}+\beta_{3}$ REFORM. Even if $\beta_{1}$ is negative, $\beta_{1}+\beta_{3}$ REFORM can be positive if the $\beta_{3}$ REFORM is positive and greater than $\beta_{1}$, when we evaluate the expression at the mean value of REFORM.

We estimate the above equations using Ordinary Least Squares.

\section{Data and Variables}

We use unit level data for the formal and informal manufacturing sectors for four years, 1989-90, 1994-95, 2000-01 and 2005-06.The choice of years is governed by the fact that the data on informal sector firms are only available for these years. ${ }^{11}$ Data on the formal manufacturing sector is drawn from the Annual Survey of Industries (ASI), undertaken by the Central Statistical Organization (CSO), which is the annual census-cum-sample survey of all the formal manufacturing units for all the industries across all the states. The ASI covers all firms registered under the Factories Act (Sivadasan 2003). The ASI frame consists of two sectors - the 'census sector' and the 'sample sector'. Firms employing less than 100 workers come under the sample sector, and roughly one-third of these firms are surveyed by the ASI, using a stratified random sampling procedure.

Our main data sources on the informal sector are the surveys on the India's unorganized or informal manufacturing establishments. ${ }^{12}$ As mentioned before, units with less than ten workers are termed informal, and are not subject to the same industrial licensing or labor laws as formal firms. These units are broadly of two types- household enterprises, which use only 
family labor and are often single-person establishments, and small business establishments with up to ten hired workers.

We limit our analysis of informal firms to those which hire outside labour, as there are serious limitations on the quality of data for family firms. One such limitation emanates from the very reason of these firms in business. Family firms (i.e. those which do not hire outside labour) are often in business simply because running a small enterprise allows them to bring in additional income with little additional effort and they are unlikely to expand or invest in their businesses (Banerjee and Duflo, 2008). As our interest is in those firms that are likely to modify their behavior in response to policy changes, we confine our analysis to those informal firms that employ at least one hired worker.

The National Sample Survey Organization (NSSO) is the agency that collects information on various aspects of the enterprises/units in the informal manufacturing sector quinquennially using a stratified random sampling procedure. These are nationwide enterprise level surveys covering all the Indian states and Union Territories (UTs) and are stratified by district. ${ }^{13}$ Since most informal enterprises are not registered with any government authority, the NSSO uses a block enumeration approach to ensure a representative sample of the informal sector in every district.

Our data is in the form of repeated cross-sections, and not in panel form, as the CSO and the NSSO do not reveal the identity of the firm/plant in the unit level data, and for the informal sector, the same firms may not be surveyed in each round. The lack of availability of panel data is a limitation of our analysis. However, given the rigorous sample survey methods used by the CSO and the NSSO to ensure the representativeness of the unit level data of the informal and formal manufacturing sectors, and the relative consistency of these methods over time, the repeated cross-sections can be seen as a close approximation of the panel data that we ideally liked to have used in our analysis.

It is to be noted that during the sixteen years of our analysis period, industrial classification has undergone some changes. For instance, ASI data for 1994-95 and 2000-01 uses NIC 1987 codes, whereas 2005-06 uses NIC 1998 codes. NSSO data for 1989-90 and 1994-95 are based on NIC 1987, whereas 2000-01 data is based on NIC 1998 and 2005-06 data is based on NIC 2004. We harmonized the whole data at NIC 1998 codes. The average number of firms over the four year period in the formal sector that we use in our empirical analysis is 25,000 and for the informal sector, $28,000 .^{14}$ 
Labour regulation data till 1997 comes from Besley and Burgess (2004), and we have updated it using similar coding procedures till 2005. ${ }^{15}$ Data on the share of credit going to the priority sector are drawn from Burgess and Pande (2005) till 1995, and we have updated it for the years 2000-01 and 2005-06 from an annual publication titled Statistical Tables Relating to Banks in India published by the Reserve Bank of India (RBI). The state-level data on the transmission and distribution losses of electricity comes from the report on Energy published by the Centre for Monitoring Indian Economy (CMIE 2011).

The variables for the stochastic frontier model are real value added and real capital stock at 1993-94 prices and number of persons employed. We omitted observations for which real value added, real capital and the labour variables are less than or equal to zero. Real value added is obtained by deflating nominal value added using the wholesale price index (WPI) for manufactured products at the four digit industry level. Labour is measured as total number of persons engaged in the production activity, which include production workers as well as employees. Real capital stock is constructed by deflating gross fixed assets by WPI for machinery and machine tools. To ensure that the empirical analysis is not sensitive to the inclusion of outliers, we have dropped all firms where real capital stock, employment or real output are more than two standard deviations from the industry means of these variables.

We obtain simple and weighted tariffs ratios from the trade and industrial output data of the World Bank Trade Data-base (World Bank 2006). The World Bank Trade Data-base provides simple and import weighted average tariffs data for 28 manufacturing sectors at the ISIC 3 digit level of classification till 2006. We match the data to the NIC 3 digit classification of the Annual Survey of Industries. Thus, our tariff variables vary across industries and over time (but not across states). ${ }^{16}$

As discussed, the de-licensing of industries started in 1980s with nearly half of the 4-digit industries de-licensed by 1985. The industrial licensing was effectively abolished in 1991 except for a small number of industries where it was retained for reasons related to security, strategic or environmental concerns. As of 2006-07, only 4 per cent of the industries were under licensing requirements. We construct the de-licensing variable as the total number of four-digit industries de-licensed in a year to that of total number of four-digit industries in the sector. Similar to Aghion et al. (2008), we consider an industry to be de-licensed if all or part of a four-digit industry (3-digit in their case) is de-licensed in a year. 
The reservation of items for exclusive manufacture in the small scale sector, as statutorily provided in the Industries (Development and Regulation) Act, 1951, was one of the key policy measures to promote the sector. Exception to this reservation was allowed only if a non-small scale sector unit undertakes 50 per cent export obligations of the reserved product. We construct the de-reservation variable as the ratio of cumulative number of products dereserved in respective two-digit industries to that of total reserved products in these industries. The list of number of products de-reserved is obtained from different notifications of the Government of India. Like tariffs, our de-licensing and de-reservation variables also vary across industries and over time, but not across states.

Figure 1 and Table 1 present the trend in de-licensing, de-reservation and tariff reforms since 1985. It is interesting to note that de-licensing and de-reservation reforms together were spread over two decades - most of the de-licensing reforms were over by 1995 , whereas dereservation reforms started after 1995. Two important points are to be noted - a) all these reforms were nationwide in nature, when an industry de-licensed or a product de-reserved or tariffs reduced, it affected all the firms irrespective of their geographical location; and b) by 2005-06, the terminal year of our study period, only six per cent of industries required delicensing, nearly one-third of products needed to be de-reserved and average tariff was 29 per cent(ranging between 24 per cent to 38 per cent), much below the 100 per cent average tariff rate that prevailed in 1991. Table 2 gives industry-wise reforms accomplished till 2005-06. It is clear from Table 2 that the pace of the three product market reforms differed greatly across industries.

\section{INSERT TABLE 1}

\section{INSERT FIGURE 1}

\section{INSERT TABLE 2}

Using the data for these three product market reforms, we construct a composite index of reform (REFORM) by assigning equal weights for all the three reforms. As the reform variables move in different directions - trade reform moves from high to low, whereas other two reforms move from low value to high with progressive reforms -we reconstruct our tariff reform variable as 100 -Current Tariff. This modification reconciles the direction of tariff reform with other two reforms. A high value of REFORM thus indicates a greater extent of reforms and a lower value indicates more restrictions and thus less reform. As indicated in Figure 2, the progress of reform is not uniform but varies significantly across industries. 
Industries like tobacco, minerals and transport equipment are far behind textiles, apparels, leather, office machinery, publishing and basic metals in these reforms.

\section{INSERT FIGURE 2}

Table 3 presents the descriptive statistics for the main variables that we use in our first stage probit model, second stage stochastic frontier estimation and third stage where we test for duality in manufacturing. On average, priority sectors such as small-scale industries, services and agriculture together received about 31 per cent of the total bank lending for the period 1989-90 to 2005-06. The labour regulation variable suggests that, on average, labour laws in India have been pro-worker. Transmission and distribution losses have, on average, been 26.49 per cent of total power availability. It is clearly evident from the Table that average value added per employee is considerably higher for firms in the formal sector as compared to their counterparts in the informal sector. Evidence also points to significant differences in the level of input use between firms in the formal and informal sector. The capital-labour ratio computed for both the sectors suggest the highly capital intensive nature of production process employed in the formal sector vis-à-vis the informal sector.

\section{INSERT TABLE 3 HERE}

\section{Results}

We first present the results for the first stage estimation followed by the results for the second stage and third stage estimation respectively.

\section{First stage estimation}

Results of the first stage probit equation estimation are presented in Table 4. The chi-square test statistic in the probit selection equation is significant at the one per cent level in all the industries. As expected, we find that weaker labour regulation (LABOUR LAWS) significantly and positively (except for Tobacco and Chemical Sectors) influences the firm's decision to be in the formal sector. Our results also confirm the existence of a negative relationship between the power transmission and distribution losses (T\&D LOSSES) and the firm's decision to be in the formal sector. ${ }^{17}$ This suggest that the greater the quality and quantity of electricity supplied in a given state (as captured by a lower amount of loss of power through transmission and distribution in the state), the more likely is it that firms in that state will be formalized. ${ }^{18}$ In most industries, greater availability of priority sector lending (PRIORITY 
SECTOR LENDING) from commercial banks seems to have been influencing the firms' decision to be in the formal sector.

\section{INSERT TABLE 4 HERE}

\section{Second stage estimation}

Table 5and Figure 3 give the summary statistics for variables used in estimating stochastic production frontier for formal and informal firms separately. As expected, in each industry the informal firms on an average use less labour and capital and produce less, though the variation is smaller for the group. These differences in input usage is also clearly evident from Figure 3 which displays kernel density plots showing cumulative differences in the logged values of value added, capital stock and labour between formal and informal sector.

\section{INSERT TABLE 5 HERE}

\section{INSERT FIGURE 3 HERE}

The maximum likelihood estimates of the parameters of the model obtained from estimating the stochastic production frontier model separately for 22 industries for each of the groups are presented for 1989-90, 1994-95, 2000-01 and 2005-06 in TablesA2 to A5 (in the Appendix)respectively. The models estimated by the maximum likelihood method are highly significant as shown by the large likelihood values. The coefficient of the selectivity variable $\left(\rho_{\mathrm{w}, \mathrm{v}}\right)$ is significantly different from zero at the five per cent level in most of the industries especially for 2000-01 and 2005-06, which confirms that serious selection bias exists, thereby supporting the use of a sample-selection framework in the stochastic frontier model. The results of the stochastic production frontier models show that the coefficient of labour is higher than that of capital for most industries and for most years irrespective of the group suggesting that labour is a more important input than capital in the production function, which is a quite plausible finding for a labour surplus economy like India. For informal sector, we find elasticity of labour or capital is negative in some industries for some years. This could be because of two reasons - first, some of these industries are highly capital intensive, thereby having less scope for informal firms (for example, Petroleum); and second, the estimates for these industries are not consistent due to less degrees of freedom as these industries consist of only few informal firms (for example, Office Machinery). We also examine whether there has been any changes in the estimated parameters of the industry production functions over time. Our results preclude any such possibility in the formal sector 
as the t-ratio for differences in coefficients is found to be insignificant for most industries and most years. However, the t-test for differences in coefficients do suggest changes in estimated parameters over time for the informal sector with the sector reporting increasing returns to scale for the later period.

Figure 4 shows the kernel density plots of efficiency of informal and formal manufacturing firms for 1989-90, 1994-95, 2000-01 and 2005-06. We observe that the efficiency distribution for formal firms is generally to the right of that for informal firms for all the years. There has been a rightward shift of both the efficiency distributions over time, indicating higher efficiency gains for both formal and informal firms over time.

\section{INSERT FIGURE 4 HERE}

\section{Third Stage Estimation: Impact of Reforms on Dualism}

We now examine how the reforms have impacted on dualism in Indian manufacturing. First, we examine the impact of reforms on efficiency of Indian manufacturing firms as in equation (8). Next, we see whether reforms have reduced or exacerbated manufacturing dualism. This is done by including the interaction term FORMAL*REFORM as in equation (9). To take into account that efficiency may be impacted by macroeconomic shocks and cyclical factors and that firm efficiency may be correlated with unobserved industry characteristics, we include year and industry fixed effects in all our regressions.

Table 6 presents the results for the third stage estimation. In Col. (1) of Table 6, we present our results on the effects of reforms and firm location in the formal sector on technical efficiency, and in Col. (5) of Table 6, we present the results with the interaction term included. The estimates suggest that formal firms are, on average, more efficient than informal firms as the coefficient of the FORMAL dummy is positive and statistically significant at one per cent level (Col. (1)). Our computations based on the coefficient value of FORMAL indicate that the efficiency level of formal firms is 17.69 per cent higher than that of informal firms. Our results also show that firms in both formal and informal sectors have gained in efficiency in the reform period as given by the positive and statistically significant coefficient of the REFORM variable in Col. (1). Based on the coefficient value of REFORM variable, we find that the gains in efficiency due to the reforms have been 28.4 per cent.

The result for equation (9) is reported in Col. (5). We find that the coefficient on the interaction term FORMAL*REFORM is positive and statistically significant. This suggests 
that the economic reforms have brought about a widening of efficiency differentials between formal and informal firms, exacerbating dualism in the Indian manufacturing sector. At the mean value of technical efficiency (0.43), our calculations show that reforms have increased the efficiency of formal firms by 50.1 per cent vis-à-vis informal firms. Together with the results in Col. (1), this suggests that both the formal firms and informal firms have registered efficiency gains in the reforms period, but these gains are significantly larger for the formal firms vis-à-vis the informal firms. Our calculations further show that an additional 10 per cent reforms (from the mean value) would have increased efficiency of formal firms by 4.5per cent, this increase however would have been only 2.5 per cent for informal firms.

\section{INSERT TABLE 6 HERE}

As we have noted in Section IV, the implementation of de-licensing, de-reservation and trade reforms differed widely across industries and over time. As is evident from Figure 2, trade reform has had a significant overlapping timeline with de-licensing and de-reservation reforms. We examine whether each of these product market reforms had a differential impact on efficiency, and on dualism. We do this by entering each reform variable sequentially rather than including all of them at the same time in equation (8). Cols. (2) to (4) in Table 6 present the results for de-licensing, de-reservation and tariff reform variables respectively. We find that de-licensing and de-reservation have had a discernible positive impact on technical efficiency, while tariff reform has had a negative effect. ${ }^{19}$ The results indicate that additional de-licensing and de-reservation reforms to the tune of 10 per cent from their mean values would have resulted in a 2.9 per cent and a 0.93 per cent increase in efficiency of Indian manufacturing firms. On the other hand, a reduction in tariffs by 10 per cent would have reduced efficiency of Indian manufacturing firms by 0.41 per cent, though the magnitude is relatively small compared to the other two sets of reforms.

To see how individual reforms have influenced manufacturing dualism, the interaction of the three reform variables with that of whether the firm is a formal firm or not (FORMAL) has been introduced sequentially. Cols. (6) to (8) of Table 6 report the results. We find that the interaction between de-licensing and FORMAL (Formal*DELICENSE) and between dereservation and FORMAL (Formal*DERESERVE) are positive and significant, while the interaction between tariff cuts and FORMAL (Formal*TARIFF) is negative and significant. This suggests that all three reforms have led to an increase in efficiency differentials between formal and informal firms. In the case of tariff reforms, though we observe a decline in 
efficiency for the overall manufacturing sector, formal firms have gained in efficiency by 0.17 per cent.

Further calculations show that additional 10 per cent de-licensing would have resulted in increased efficiency of formal firms by 3.5per cent, while the increase in efficiency for informal firms would have been only 1.7 per cent. Similarly, a 10 per cent tariff reduction would have increased efficiency of formal firms by 0.3 per cent, whereas it would have resulted in decline in efficiency of informal firms by 1.5 per cent. Lastly, additional dereservation of 10 per cent would have resulted in an increase in efficiency of formal firms by 0.7 per cent but would have led to a decline in the efficiency of informal firms marginally by 0.05 per cent.

A potential cause for concern in our third-stage analysis is if the de-licensing, de-reservation and tariff reforms themselves determined whether a firm decided to locate in the formal or informal sector in the first-stage analysis. For instance, de-licensing may have made it easier for informal firms to move to the formal sector, while de-reservation would have reduced the incentives of firms to remain small to avail of the benefits of reservation policy. With respect to tariff reform, tariff cuts are not expected to influence the firm's formalization decision as the removal of import protection applied to all firms in the manufacturing sector. With respect to de-licensing, as mentioned in Section II, entry barriers for small firms had eased considerably by the mid-eighties and the de-licensing reforms of the 1990s mostly focused on the removal of constraints to capacity expansion for firms in the formal sector, as well as reducing the number of industries reserved for the public sector (Mookherjee 1995). This implies that de-licensing reforms would not have affected the informal firm's decision to formalise in our period of analysis, since the beginning year in our case is 1989. Similarly, it is unlikely that de-reservation would have influenced the decisions of informal firms to locate to the formal sector, as the majority of firms in our data-set that met the criteria of being 'small' under the reservation policy (as defined by the size of the capital stock) were far below the threshold size (in terms of number of workers) for graduation to the formal sector. Still we tested for the possibility that our REFORM variable may have influenced the firm's decision to formalize by including the latter in our first-stage industry-level selection equations. We found that this variable was statistically insignificant in a majority of the industries. $^{20}$ 
Finally, an important remaining concern is the possible endogeneity of the composite REFORM variable. ${ }^{21}$ If policy-makers introduced economic reforms in the most efficient industries or where the most productive formal firms were located, reverse causality may explain the positive coefficients on the REFORM variable and on the interaction term between the two key explanatory variables, REFORM and FORMAL. In our case, economic reforms would be endogenous to performance if either trade opening or de-licensing or dereservation were endogenous (or a combination of the three set of reforms were endogenous). However, several features of the reforms mitigate the concerns of endogeneity in the Indian case.

Firstly, with respect to de-licensing reforms of the post-1991 period, Aghion et al. (2008) argue that de-licensing was a centrally managed technocratic reform, triggered in part by largely unexpected shocks (brought about the increase in oil prices and the drop in remittances, following the Gulf War) and the IMF-imposed structural adjustment programme, and that the industries that were not de-licensed in the post-1991 period were not done so for political reasons but because of their strategic, environmental and social importance. Testing for the endogeneity of de-licensing reforms, they find no evidence of a relationship between when an industry is de-licensed and pre-reform measures of performance.

Secondly, with respect to de-reservation reforms, Tewari (2011) finds that pre-reform industry characteristics that should be able to predict the timing of de-reservation in a particular industry if the reforms were politically determined and endogenous to past performance, are not able to explain why some products were de-reserved earlier than others, suggesting that these reforms had no systematic relationship with pre-reform efficiency of firms in a given industry.

Finally, with respect to tariff reform, as argued by Topalova (2010):

"the timing of the trade liberalisation was unanticipated, as it was sudden and externally imposed. Thus, it was not part of a well-planned development strategy that would have given households and firms the opportunity to adjust their employment, consumption and production decisions in anticipation of trade liberalisation... Indeed, the reforms were implemented so fast that they did not appear on the political radar" (pages 5-6).

Topalova $(2004,2007)$ also shows that there is no correlation between future tariffs and current productivity, and that tariff changes were not correlated with pre-reform sectoral 
characteristics such as number of employees, industrial concentration, and the share of skilled workers, that may suggest that less efficient industries received politically protection.

To test for the endogeneity of reforms formally, we regress the reform variable at time $t$ on absolute efficiency levels of formal and informal firms at time t-1. While the coefficient on the reform variable is positive, it is not statistically significant from zero. Thus, there is no evidence to suggest that there is a systematic relationship between the timing of reforms and past performance, allaying possible endogeneity concerns on the REFORM variable.

\section{Conclusions}

Do economic reforms reduce or exacerbate manufacturing dualism? We investigate this question using firm level data for the informal and formal manufacturing for the Indian economy combined from four repeated cross-sections over the period 1989-2005. We use stochastic frontier analysis applied to twenty-two industries to calculate efficiency at the firm-level for the Indian economy for both formal and informal firms separately. We use the econometric methodology proposed by Greene (2010) to correct for selection bias in the firm's decision to be in the informal or formal sectors in the estimates of efficiency. We then estimate the effects of key product market reforms enacted in India since the mid 1980s tariff reforms, industrial de-licensing and the scaling back of small sector reservation policy on efficiency differentials between informal and formal firms.

Our regression results suggest that economic reforms have had an unambiguous positive effect on absolute levels of technical efficiency in the entire manufacturing sector (both informal and formal sectors combined). While average efficiency levels in both the informal and the formal manufacturing sectors have increased, the increase has been more for the formal firms. We also find that economic reforms have increased the efficiency differentials between the more efficient formal firms and the less efficient informal firms in Indian manufacturing, and that all three product market reforms have contributed to greater dualism in the manufacturing sector in the post-reform period.

Our findings on the role of economic reforms in increasing dualism in the manufacturing sector in India can be interpreted in two ways. One interpretation could be that there has been an increasing movement of the more efficient informal firms to the formal sector, and the entry of these firms into the formal sector has led to a widening differential inefficiency levels between the informal and formal sectors. However, such an interpretation that suggests 
a fairly strong mobility of efficient informal firms to the formal sector does not seem to be supported by the data. The share of the informal sector in total manufacturing employment was 82 per cent in 1989-90, and was marginally lower at 80.5 per cent in 2005-06, sixteen years later. Similarly, the share of the informal sector in the total manufacturing output was 20.7 per cent in 1989-90 and was again marginally lower at 18 per cent in 2005-06. A second interpretation that is more consistent with the available evidence is that the informal sector is increasingly lagging behind in performance. This is reflected in an increase in the ratio of labour productivity of the formal sector to the informal sector, which went up from 12.3 in $1989-90$ to 16.8 in 2005-06. This suggests that the conventional view on why the Indian manufacturing has had high levels of manufacturing dualism which attributes the latter to the restrictive policy regime followed in India till the early 1990s does not seem to be supported by the findings of this paper. While economic reforms have had an overall efficiencyenhancing effect on Indian manufacturing, they have benefited formal firms more than informal firms.

Our results have important implications for the effects of economic reforms on pro-poor growth in emerging economies. While economic reforms can have strong positive effects on overall efficiency in the manufacturing sector, the widening gap between the productivity of formal and informal firms in manufacturing will make it difficult for informal firms to compete in external and domestic markets that are increasingly integrated. Given the large presence of unskilled and semi-skilled workers in the workforce of the informal sector, such a process of dualistic development may act as a significant obstacle for the poverty reducing and employment creating impact of economic growth. 


\section{REFERENCES}

Aghion, P., R. Burgess, S. Redding, and F. Zilibotti (2008), "The Unequal Effects of Liberalization: Evidence from Dismantling the License Raj in India", American Economic Review, Vol. 98, No. 4, pp. 1397-1412.

Ahsan, A. and C. Pagés (2009), "Are All Labor Regulations Equal? Evidence from Indian Manufacturing”, Journal of Comparative Economics, Vol. 37, p. 62-75.

Aigner, D.J., C.A.K. Lovell, and P. Schmidt (1977), "Formulation and estimation of stochasticfrontier production function models", Journal of Econometrics, Vol. 6, pp. 2137.

Alessandrini, M., Fattouh, B., Ferrarini, B. and Scaramozzino, P. (2011), "Tariff liberalization and trade specialization: Lessons from India”, Journal of Comparative Economics, Vol. 39, No.4, pp. 499-513.

Banerjee, A. V. and Duflo, E. (2008) "What is middle class about the middle classes around the world?," Journal of Economic Perspectives, Vol. 22 (2), pp. 3-28.

Besley, T. and Burgess, R. (2004). "Can Labour Regulation Hinder Economic Performance? Evidence from India”, The Quarterly Journal of Economics, Vol. 119(1), pp. 91-134.

Bhagwati, J. and Srinivasan, T. N. (1975) Foreign Trade Regimes and Economic Development: India. New York: Columbia University Press.

Bond, S. R. and Malik, A. (2007), Explaining cross-country variation in investment: the role of endowments, institutions and finance, Mimeo, Oxford University.

Bourguignon F. and C. Morrison (1998), "Inequality and Development: The Role of Dualism”, Journal of Development Economics, Vol.57 (2), pp.233-257.

Burgess R. and R. Pande (2005), "Do Rural Banks Matter? Evidence from the Indian Social Banking Experiment”, American Economic Review, Vol. 95(3), pp. 780-795.

Centre for Monitoring Indian Economy (CMIE, 2011), Report on Energy, Bombay.

Chari, A.V (2011), "Identifying the Aggregate Productivity Effects of Entry and Size Restrictions, American Economic Journal: Economic Policy, Vol. 3, pp. 66-96.

Charmes, J. (2000), The Contribution of Informal Sector to GDP in Developing Countries: Assessment, Estimates, Methods, Orientations for the Future, Paper presented at the $4^{\text {th }}$ Meeting of the Delhi Group on Informal sector Statistics, Geneva.

Charmes, J. (2006), Measurement of the Contribution of Informal Sector and Informal Employment to GDP in Developing Countries: Some Conceptual and Methodological Issues, Paper presented at the $9^{\text {th }}$ Meeting of the Delhi Group on Informal sector Statistics, New Delhi.

Dabla-Norris, E., Gradstein, M. and Inchauste, G. (2005) What Causes Firms to Hide Output? The Determinants of Informality, IMF Working Paper No. 05/160, IMF, Washington DC. 
Dessy, S. and Pallage, S (2003), "Taxes, inequality and the size of the informal sector", Journal of Development Economics, Vol. 70, pp. 225-233.

de Vries, G.J., Erumban, A.A., Timmer, M.P., Voskoboynikov, I. and Wu, H. X. (2012), "Deconstructing the BRICs: Structural transformation and aggregate productivity growth", Journal of Comparative Economics, Forthcoming.

Dougherty, S. (2008), "Labour Regulation and Employment Dynamics at the State level in India." OECD Economics Department Working Papers, No. 624.

Fajnzylber, W.F. Maloney and G.V. Montes-Rojas (2011), "Does formality improve microfirm performance? Quasi-Experimental Evidence from the Brazilian SIMPLES program”, Journal of Development Economics, Vol. 94(1): 262-276.

Gang, I.(1992), “Small Firm 'Presence' in Indian Manufacturing”, World Development, Vol. 20, No. 9, pp. 1377-1389.

Government of India (1991), Statement of Industrial Policy. New Delhi.

Greene, W. (2006) A General Approach to Incorporating 'Selectivity' in a Model, Working Paper EC-06-10, Stern School of Business, New York University.

Greene, W. (2010), “A stochastic frontier model with correction for sample selection”, Journal of Productivity Analysis, Vol. 34, pp.15-24.

Heckman J. J. (1976), The Common Structure of Statistical Models of Truncation, Sample Selection and Limited Dependent Variables and a Simple Estimator for Such Models, Annals of Economic and Social Measurement, Vol. 5, pp. 475-492.

International Labour Organisation (ILO) (2002), Decent work and the informal economy, Geneva: ILO.

Joshi, V. (2010), "Economic Resurgence, Lopsided Reform and Jobless Growth", in A. Heath and R. Jeffrey (eds.), Continuity and Change in Contemporary India: Politics, Economics and Society, Oxford University Press.

Kanbur, R.(2011) “Avoiding Informality Traps.” In E. Ghani (Ed.) Reshaping Tomorrow: Is South Asia Ready for the Big Leap? pp. 260-278, Oxford University Press.

Kathuria, V. Raj, R.S.N. and K. Sen (2010), Organised versus Unorganised Manufacturing Performance in the Post-Reform Period", Economic and Political Weekly, Vol. 45. No. 24, pp. 55-64.

Kochhar, K., U. Kumar, R. Rajan, A. Subramanian, and I. Tokatlidis (2006), "India's Pattern of Development: What happened, what follows?",Journal of Monetary Economics, Vol.53, pp. 981-1019.Kotwal, A., B. Ramaswami and W. Wadhwa (2011) Economic Liberalization and Indian Economic Growth: What's the Evidence? Journal of Economic Literature, 49(4), pp. 1152-1199.

Krueger, A.O. and S. Chinoy (2002), "The Indian Economy in a Global Context”, in A.O. Krueger (ed.), Economic Policy Reforms and the Indian Economy, Chicago: University of Chicago Press. 
Kulshreshtha (2011), "Measuring the Unorganised Sector in India", Review of Income and Wealth, May, pp. S123-S134.

Kumbhakar, S. and C.A. Knox Lovell (2000), Stochastic Frontier Analysis, Cambridge: Cambridge University Press.

Little, I.M.D. (1987), "Small Manufacturing Enterprises in Developing Countries", World Bank Economic Review, Vol. 1: 2, pp. 203-206.

Little, I,M.D., D. Mazumdar and J.M. Page Jr. (1987), Small Manufacturing Enterprises: A Comparative Analysis of India and Other Economies, Oxford. Oxford University Press.

Mazumdar, D. and Sarkar, S. (2008), Globalization, Labour Markets and Inequality in India, Oxon: Routledge.

Mohan, R. (2002), "Small-scale Industry Policy in India: A Critical Evaluation", in A.O. Krueger (ed.), Economic Policy Reforms and the Indian Economy, Chicago: University of Chicago Press.

Mookherjee, D. (1995), "Introduction" in D. Mookherjee (ed.), Indian Industry: Policies and Performance, pp. 1-43, Oxford: Oxford University Press.

National Commission for Enterprises in the Unorganised Sector (NCEUS), Government of India (2007), Conditions of Work and Promotion of Livelihood in the Unorganised Sector. Report, Government of India, New Delhi.

National Commission for Enterprises in the Unorganised Sector (NCEUS), Government of India (2009), The Challenge of Employment in India: An Informal Economy Perspective. Report.

NSSO (2007), Operational characteristics of unorganized manufacturing enterprises in India, $62^{\text {nd }}$ Round, Ministry of Statistics and Programme Implementation, Government of India

Pais, J. (2008), Effectiveness of Labour Regulations in Indian Industry, New Delhi: Bookwell Publishers.

Panagariya, A (2008),India: The Emerging Giant, New York: Oxford University Press.

Schmitz, H. (1982), "Growth Constraints on Small-scale Manufacturing in Developing Countries: A Critical Review”, World Development, Vol. 10, No. 6, pp. 429-450.

Schneider, F. (2002) Size and Measurement of the Informal Economy in 110 countries around the world (http://rru.worldbank.org/Documents/PapersLinks/informal_economy.pdf)

Sen, K. (2008), Trade Policy, Inequality, and Performance in Indian Manufacturing, London: Routledge Advances in South Asian Studies.

Sen, K. and R.R. Vaidya (1997), The Process of Financial Liberalization in India, Delhi: Oxford University Press. 
Straub, S. (2005), "Informal sector: the credit channel”, Journal of Development Economics, Vol. 78, pp. 299-321.

Taymaz, E. (2005), “Are Small Firms Really Less Productive?”, Small Business Economics, Vol. 25, pp. 429-445.

Taymaz, E. (2009) "Informality and Productivity: Productivity Differentials between Formal and Informal firms in Turkey", ERC Working Papers, 0901, Economic Research Centre, Middle East Technical University, Ankara (http://www.erc.metu.edu.tr/menu/series09/ 0901.pdf accessed in December 2010).

Taymaz, E. and G. Saatci (1997), “Technical change and efficiency in Turkish manufacturing industries”, Journal of Productivity Analysis, Vol. 8, pp. 461-475.

Temple, J. R. W. (2005). Dual economy models: a primer for growth economists. The Manchester School, Vol. 73, No. 4, pp. 435-478.

Tewari, I. (2011), Is small beautiful? Evidence from India's product reservation policy for small industry, Mimeo, Brown University.

Topalova, P. (2004), Trade liberalization on productivity: The case of India, Working Paper No. 04/28, International Monetary Fund.

Topalova, P. (2007), "Trade liberalization, poverty and inequality: Evidence from Indian districts". In Globalization and Poverty, ed. Ann Harrison, 291-336. Chicago: University of Chicago Press.

Topalova, P. (2010), "Factor immobility and regional impacts of trade liberalization: Evidence on Poverty in India", American Economic Journal: Applied Economics, Vol. 2, No. 4: 1-41.

Tybout, J. (2000), "Manufacturing Firms in Developing Countries: How Well They Do, and Why?", Journal of Economic Literature, Vol. 38, pp. 11-44.

Ulyssea, G. (2010), "Regulation of entry, labor market information and the informal sector", Journal of Development Economics, Vol. 91, pp.87-99.

World Bank (2004), India Investment Climate Assessment 2004: Improving Manufacturing Competitiveness, Washington D C; The World Bank.

World Bank (2005), World Development Report 2005: A Better Investment Climate For Everyone, Washington D C: The World Bank.

World Bank (2006). Trade, Production and Protection, 1976-2004, available on www.worldbank.org/trade.

WTO (2009), Globalization and Informal Jobs in Developing Countries, Geneva: World Trade Organization and International Labour Office.

Yang, C-H. and J-H. Chen (2009), “Are small firms less efficient?”, Small Business Economics, Vol. 32, pp.375-395. 
Table 1: Trend in Reform variables

\begin{tabular}{lrrrr}
\hline & $\mathbf{1 9 8 9 - 9 0}$ & $\mathbf{1 9 9 4 - 9 5}$ & $\mathbf{2 0 0 0 - 0 1}$ & $\mathbf{2 0 0 5 - 0 6}$ \\
\hline De-licensing (per cent of 4-digit & 53.02 & 84.41 & 93.47 & 93.82 \\
industries de-licensed) & $(36.85)$ & $(26.28)$ & $(21.64)$ & $(21.42)$ \\
De-reservation (per cent of products & 9.09 & 9.09 & 15.30 & 70.83 \\
de-reserved) & $(29.42)$ & $(29.42)$ & $(30.4)$ & $(32.13)$ \\
Trade reforms (Tariffs in per cent) & 76.67 & 56.09 & 31.80 & 29.02 \\
& $(15.0)$ & $(10.1)$ & $(4.55)$ & $(3.93)$ \\
\hline
\end{tabular}

Note: Figures in parenthesis are the standard deviations.

Table2: Industry-wise status of Reforms, 2005-06

\begin{tabular}{lccc}
\hline Industry & $\begin{array}{c}\text { De-licensed (in } \\
\text { per cent) }\end{array}$ & $\begin{array}{c}\text { De-reserved (in } \\
\text { per cent) }\end{array}$ & $\begin{array}{c}\text { Tariff (in } \\
\text { per cent) }\end{array}$ \\
\hline Food Products & 93.8 & 62.5 & 37.79 \\
Tobacco & 0.0 & 100 & 30.00 \\
Textiles & 100.0 & 100 & 27.06 \\
Wearing Apparel & 100.0 & 100 & 29.93 \\
Leather Products & 100.0 & 100 & 28.23 \\
Wood and Wood Products & 100.0 & 43.75 & 29.22 \\
Paper and Paper Products & 100.0 & 38.71 & 27.05 \\
Publishing & 100.0 & 100 & 23.57 \\
Coke and Petroleum & 100.0 & 100 & 29.71 \\
Chemicals & 84.6 & 78.19 & 28.57 \\
Rubber \& plastic products & 100.0 & 36.90 & 29.56 \\
Non-Metallic Mineral Products & 100.0 & 10 & 29.25 \\
Basic metal & 100.0 & 100 & 33.50 \\
Metal products & 100.0 & 64.66 & 28.66 \\
Machinery & 100.0 & 78.79 & 25.10 \\
Office machinery & 100.0 & 100 & 25.10 \\
Electrical machinery & 100.0 & 54.05 & 24.57 \\
Radio \& Television & 100.0 & 83.33 & 24.74 \\
Medical, precision inst. & 100.0 & 80 & 24.74 \\
Motor vehicles & 100.0 & 100 & 36.02 \\
Transport equipment & 85.7 & 5.88 & 36.02 \\
Furniture & 100.0 & 21.43 & 30.00 \\
\hline Average & $\mathbf{9 3 . 8}$ & $\mathbf{7 0 . 8 3}$ & $\mathbf{2 9 . 0 2}$ \\
\hline
\end{tabular}


Table 3: Descriptive statistics at the aggregate level: 1989-2006

\begin{tabular}{lrr}
\hline & Mean & Standard deviation \\
\hline Selection Variables & & \\
Labour regulation index (pro-worker: +1; pro-employer: -1) & 0.576 & 0.235 \\
Transmission and distribution losses (as percentage of total & & \\
power availability) & 26.49 & 8.348 \\
Share of priority sector lending, state-level (per cent) & 31.457 & 9.883 \\
Firm size (log (ln) employment) & 2.652 & 1.557 \\
\hline Stochastic Frontier Variables & & \\
Ln formal manufacturing value added per employee & 10.719 & 1.126 \\
Ln informal manufacturing value added per employee & 8.920 & 1.199 \\
Ln formal manufacturing capital labour ratio & 10.454 & 1.727 \\
Ln informal manufacturing capital labour ratio & 9.821 & 1.341 \\
Ln formal manufacturing employment (No.) & 3.893 & 1.211 \\
Ln informal manufacturing employment (No.) & 1.404 & 0.529 \\
\hline Reform Variables & & \\
REFORM (weighted Reform measure) & 52.58 & 19.50 \\
De-licensing (per cent of four-digit industries de-licensed) & 81.6 & 31.2 \\
De-reservation (per cent of products de-reserved) & 26.07 & 48.39 \\
Trade liberalization (Tariff in per cent) & 48.39 & 21.66 \\
\hline Notes: The data are for the 15 major sates for the period 1989-2006. Since Bihar, MP and UP were bifurcated in \\
$\quad$ 2000 to form the new states, Uttarakhand, Chhattisgarh and Jharkhand, we have merged these three \\
$\quad$ states with their parent states so as to have consistent data for the study period.
\end{tabular}


Table 4: Parameter Estimates of the Probit Selection Equation, Industry Level, All Years

\begin{tabular}{|c|c|c|c|c|c|c|c|c|}
\hline Industries & Constant & $\begin{array}{l}\text { LABOUR } \\
\text { LAWS }\end{array}$ & $\begin{array}{c}\text { T \& D } \\
\text { LOSSES }\end{array}$ & $\begin{array}{c}\text { PRIORITY } \\
\text { SECTOR } \\
\text { LENDING }\end{array}$ & $\begin{array}{c}\text { Log } \\
\text { likelihood }\end{array}$ & $\begin{array}{c}\text { McFadden } \\
\text { R-square }\end{array}$ & $\mathbf{N}$ & $\begin{array}{c}\text { Chi- } \\
\text { squared }\end{array}$ \\
\hline Food & $\begin{array}{l}-0.285^{*} \\
(0.034)\end{array}$ & $\begin{array}{l}0.766^{*} \\
(0.030)\end{array}$ & $\begin{array}{l}-0.006^{*} \\
(0.001)\end{array}$ & $\begin{array}{c}0.001 \\
(0.001)\end{array}$ & -26534.62 & 0.02 & 38978 & 259.73 \\
\hline Tobacco & $\begin{array}{l}-0.711 * \\
(0.113)\end{array}$ & $\begin{array}{c}-0.583^{*} \\
(0.086)\end{array}$ & $\begin{array}{l}0.021 * \\
(0.003)\end{array}$ & $\begin{array}{l}0.021 * \\
(0.003)\end{array}$ & -3006.66 & 0.02 & 4449 & 564.37 \\
\hline Textiles & $\begin{array}{l}-0.665^{*} \\
(0.038)\end{array}$ & $\begin{array}{l}0.584 * \\
(0.033)\end{array}$ & $\begin{array}{l}-0.004^{*} \\
(0.001)\end{array}$ & $\begin{array}{l}0.002 * \\
(0.001)\end{array}$ & -22827.73 & 0.01 & 35138 & 504.03 \\
\hline Apparel & $\begin{array}{l}-0.159^{*} \\
(0.068)\end{array}$ & $\begin{array}{l}0.879 * \\
(0.065)\end{array}$ & $\begin{array}{l}-0.039 * \\
(0.002)\end{array}$ & $\begin{array}{c}0.001 \\
(0.002)\end{array}$ & -6405.79 & 0.08 & 12320 & 552.01 \\
\hline Leather & $\begin{array}{l}-0.321^{*} \\
(0.101)\end{array}$ & $\begin{array}{l}1.084^{*} \\
(0.088)\end{array}$ & $\begin{array}{l}-0.027^{*} \\
(0.003)\end{array}$ & $\begin{array}{l}0.012 * \\
(0.002)\end{array}$ & -2560.40 & 0.08 & 4035 & 179.02 \\
\hline Wood & $\begin{array}{l}-0.480 * \\
(0.074)\end{array}$ & $\begin{array}{c}0.090 \\
(0.068)\end{array}$ & $\begin{array}{l}-0.016^{*} \\
(0.002)\end{array}$ & $\begin{array}{l}0.008 * \\
(0.002)\end{array}$ & -5534.87 & 0.01 & 9400 & 431.43 \\
\hline Paper & $\begin{array}{l}0.618^{*} \\
(0.110)\end{array}$ & $\begin{array}{l}1.061 * \\
(0.112)\end{array}$ & $\begin{array}{l}-0.014 * \\
(0.003)\end{array}$ & $\begin{array}{l}-0.004 \\
(0.002)\end{array}$ & -1942.50 & 0.04 & 3692 & 111.96 \\
\hline Publishing & $\begin{array}{c}0.024 \\
(0.073)\end{array}$ & $\begin{array}{l}0.226^{*} \\
(0.069)\end{array}$ & $\begin{array}{l}-0.024^{*} \\
(0.002)\end{array}$ & $\begin{array}{l}0.009 * \\
(0.002)\end{array}$ & -4741.86 & 0.03 & 7122 & 157.55 \\
\hline Petroleum & $\begin{array}{l}0.905 * \\
(0.223)\end{array}$ & $\begin{array}{l}1.882 * \\
(0.254)\end{array}$ & $\begin{array}{l}-0.012^{*} \\
(0.006)\end{array}$ & $\begin{array}{l}-0.015^{*} \\
(0.006)\end{array}$ & -464.54 & 0.07 & 1206 & 69.81 \\
\hline Chemicals & $\begin{array}{l}1.189 * \\
(0.073)\end{array}$ & $\begin{array}{l}-0.215^{*} \\
(0.067)\end{array}$ & $\begin{array}{l}-0.015^{*} \\
(0.002)\end{array}$ & $\begin{array}{l}0.008 * \\
(0.001)\end{array}$ & -5344.94 & 0.01 & 11649 & 304.12 \\
\hline Rubber & $\begin{array}{l}-0.051 \\
(0.075)\end{array}$ & $\begin{array}{l}0.646 * \\
(0.077)\end{array}$ & $\begin{array}{l}-0.009 * \\
(0.002)\end{array}$ & $\begin{array}{l}0.012 * \\
(0.002)\end{array}$ & -4235.51 & 0.03 & 6848 & 105.18 \\
\hline Minerals & $\begin{array}{l}-0.005 \\
(0.055)\end{array}$ & $\begin{array}{l}0.177 * \\
(0.052)\end{array}$ & $\begin{array}{l}-0.020^{*} \\
(0.001)\end{array}$ & $\begin{array}{l}0.023 * \\
(0.001)\end{array}$ & -10677.13 & 0.04 & 16634 & 282.01 \\
\hline Basic metal & $\begin{array}{l}1.465^{*} \\
(0.086)\end{array}$ & $\begin{array}{l}0.647 * \\
(0.087)\end{array}$ & $\begin{array}{l}-0.020 * \\
(0.002)\end{array}$ & $\begin{array}{l}-0.008 * \\
(0.002)\end{array}$ & -3085.88 & 0.02 & 7594 & 128.28 \\
\hline Metal products & $\begin{array}{l}-0.080 * \\
(0.046)\end{array}$ & $\begin{array}{l}0.198 * \\
(0.047)\end{array}$ & $\begin{array}{l}-0.019 * \\
(0.001)\end{array}$ & $\begin{array}{l}0.006 * \\
(0.001)\end{array}$ & -11357.96 & 0.01 & 17146 & 451.14 \\
\hline Machinery & $\begin{array}{l}0.358 * \\
(0.056)\end{array}$ & $\begin{array}{l}0.953 * \\
(0.056)\end{array}$ & $\begin{array}{l}-0.002 \\
(0.002)\end{array}$ & $\begin{array}{l}-0.015^{*} \\
(0.001)\end{array}$ & -8720.44 & 0.02 & 13571 & 489.35 \\
\hline $\begin{array}{l}\text { Office } \\
\text { machinery }\end{array}$ & $\begin{array}{c}0.577 \\
(0.421)\end{array}$ & $\begin{array}{c}0.062 \\
(0.468)\end{array}$ & $\begin{array}{l}-0.016 \\
(0.014)\end{array}$ & $\begin{array}{l}0.031 * \\
(0.011)\end{array}$ & -106.10 & 0.06 & 294 & 14.22 \\
\hline $\begin{array}{l}\text { Electrical } \\
\text { machinery }\end{array}$ & $\begin{array}{l}0.470 * \\
(0.086)\end{array}$ & $\begin{array}{l}0.788 * \\
(0.091)\end{array}$ & $\begin{array}{l}-0.020 * \\
(0.002)\end{array}$ & $\begin{array}{l}0.005 * \\
(0.002)\end{array}$ & -3141.43 & 0.04 & 5281 & 60.18 \\
\hline $\begin{array}{l}\text { Radio \& } \\
\text { Television }\end{array}$ & $\begin{array}{l}0.371 * \\
(0.206)\end{array}$ & $\begin{array}{l}0.952 * \\
(0.231)\end{array}$ & $\begin{array}{l}-0.006 \\
(0.006)\end{array}$ & $\begin{array}{l}0.014 * \\
(0.005)\end{array}$ & -483.88 & 0.05 & 1353 & 34.13 \\
\hline $\begin{array}{l}\text { Medical, } \\
\text { precision \& } \\
\text { optical instrmnts }\end{array}$ & $\begin{array}{l}0.598 * \\
(0.169)\end{array}$ & $\begin{array}{l}1.870 * \\
(0.188)\end{array}$ & $\begin{array}{l}-0.008 \\
(0.005)\end{array}$ & $\begin{array}{l}-0.019 * \\
(0.004)\end{array}$ & -692.14 & 0.07 & 1427 & 72.44 \\
\hline Motor vehicles & $\begin{array}{l}1.029 * \\
(0.136)\end{array}$ & $\begin{array}{l}0.191 * \\
(0.141)\end{array}$ & $\begin{array}{l}-0.017 * \\
(0.003)\end{array}$ & $\begin{array}{l}0.005 * \\
(0.002)\end{array}$ & -1554.23 & 0.01 & 3162 & 30.85 \\
\hline $\begin{array}{l}\text { Transport } \\
\text { equipment }\end{array}$ & $\begin{array}{l}0.753^{*} \\
(0.125)\end{array}$ & $\begin{array}{l}0.884 * \\
(0.133)\end{array}$ & $\begin{array}{c}0.002 \\
(0.003)\end{array}$ & $\begin{array}{l}-0.019 * \\
(0.002)\end{array}$ & -1838.68 & 0.02 & 3241 & 139.72 \\
\hline Furniture & $\begin{array}{l}-1.082^{*} \\
(0.063)\end{array}$ & $\begin{array}{l}0.508 * \\
(0.059)\end{array}$ & $\begin{array}{l}-0.006^{*} \\
(0.002)\end{array}$ & $\begin{array}{l}-0.002 \\
(0.002)\end{array}$ & -6326.45 & 0.01 & 14843 & 214.58 \\
\hline
\end{tabular}

Notes: a) $\mathrm{N}$ is the total number of firms; b) *indicates level of significance at 5 per cent; c) Figures in parenthesis are standard errors. 
Table 5: Summary statistics for second stage estimation - average over 1989-90 to 2005-06

\begin{tabular}{|c|c|c|c|c|c|c|}
\hline \multirow{2}{*}{ Industry } & \multicolumn{3}{|c|}{ Informal Sector } & \multicolumn{3}{|c|}{ Formal Sector } \\
\hline & $\mathbf{Y}$ & $\mathbf{K}$ & $\mathbf{L}$ & $\mathbf{Y}$ & $\mathbf{K}$ & $\mathbf{L}$ \\
\hline \multirow{2}{*}{ Food } & 9.96 & 10.99 & 1.24 & 14.52 & 14.32 & 4.01 \\
\hline & $(6.93-13.04)$ & $(7.36-14.50)$ & $(0.69-2.48)$ & $(10.68-18.54)$ & $(9.39-19.30)$ & $(1.39-6.73)$ \\
\hline \multirow{2}{*}{ Tobacco } & 9.63 & 10.18 & 1.39 & 13.85 & 11.77 & 4.21 \\
\hline & $(6.99-12.26)$ & $(7.07-13.12)$ & $(0-3.18)$ & $(9.37-18.44)$ & $(3.58-18.92)$ & $(0.69-7.95)$ \\
\hline \multirow{2}{*}{ Textiles } & 10.37 & 10.93 & 1.57 & 15.10 & 15.12 & 4.34 \\
\hline & $(7.44-13.20)$ & $(7.40-14.32)$ & $(0.69-2.71)$ & (11.12-19.15) & $(9.96-20.21)$ & $(1.61-7.36)$ \\
\hline \multirow{2}{*}{ Apparel } & 9.84 & 11.14 & 1.14 & 15.38 & 14.90 & 4.69 \\
\hline & $(6.72-13.11)$ & $(8.80-13.53)$ & $(0.69-2.20)$ & $(12.19-18.40)$ & $(10.67-18.89)$ & $(2.08-7.21)$ \\
\hline \multirow{2}{*}{ Leather } & 10.51 & 11.02 & 1.40 & 14.74 & 14.64 & 4.01 \\
\hline & $(7.43-13.57)$ & $(7.81-14.15)$ & $(0.69-2.56)$ & $(11.32-18.08)$ & (10.49-18.69) & $(1.39-6.73)$ \\
\hline \multirow{2}{*}{ Wood } & 10.19 & 10.90 & 1.27 & 12.98 & 12.63 & 2.88 \\
\hline & $(7.26-12.96)$ & $(6.96-14.59)$ & $(0.69-2.30)$ & (10.13-16.04) & $(8.27-16.87)$ & $(1.10-5.07)$ \\
\hline \multirow{2}{*}{ Paper } & 11.07 & 12.12 & 1.63 & 14.55 & 14.60 & 3.63 \\
\hline & $(7.89-14.17)$ & $(8.82-15.14)$ & $(0.69-2.83)$ & $(11.00-18.35)$ & $(10.19-19.36)$ & $(1.39-6.34)$ \\
\hline \multirow{2}{*}{ Publishing } & 10.28 & 11.92 & 1.34 & 14.23 & 14.01 & 3.62 \\
\hline & $(7.10-13.29)$ & $(8.43-15.05)$ & $(0.69-2.40)$ & $(10.63-17.93)$ & $(9.01-18.93)$ & $(1.39-6.14)$ \\
\hline \multirow{2}{*}{ Petroleum } & 10.43 & 11.71 & 1.63 & 14.72 & 14.99 & 3.73 \\
\hline & $(7.21-13.51)$ & $(8.12-15.04)$ & $(0.69-2.71)$ & $(10.41-19.71)$ & $(9.97-20.38)$ & $(1.10-6.66)$ \\
\hline \multirow{2}{*}{ Chemicals } & 11.04 & 12.06 & 1.82 & 15.15 & 14.91 & 4.14 \\
\hline & $(7.51-14.54)$ & $(8.43-15.50)$ & $(0.69-3.14)$ & $(11.00-19.57)$ & $(9.58-20.44)$ & $(1.61-6.98)$ \\
\hline \multirow{2}{*}{ Rubber } & 11.25 & 12.47 & 1.64 & 14.64 & 14.64 & 3.55 \\
\hline & $(7.82-14.54)$ & $(8.76-15.82)$ & $(0.69-2.77)$ & (11.26-18.27) & $(10.64-18.92)$ & $(1.39-6.13)$ \\
\hline \multirow{2}{*}{ Minerals } & 10.59 & 11.42 & 1.83 & 13.75 & 13.36 & 3.65 \\
\hline & $(7.45-13.73)$ & $(7.60-15.08)$ & $(0.69-3.56)$ & $(10.20-17.87)$ & $(8.84-18.57)$ & $(1.39-6.25)$ \\
\hline \multirow{2}{*}{ Basic metal } & 10.76 & 11.86 & 1.55 & 14.97 & 14.98 & 3.97 \\
\hline & $(7.31-14.27)$ & $(8.23-15.43)$ & $(0.69-2.77)$ & $(11.10-19.18)$ & $(10.15-20.13)$ & $(1.39-6.86)$ \\
\hline \multirow{2}{*}{ Metal products } & 10.54 & 11.52 & 1.35 & 14.23 & 13.83 & 3.50 \\
\hline & $(7.44-13.55)$ & $(8.13-14.66)$ & $(0.69-2.40)$ & $(10.87-17.89)$ & $(9.67-18.19)$ & $(1.39-6.11)$ \\
\hline \multirow{2}{*}{ Machinery } & 10.79 & 11.91 & 1.41 & 14.54 & 14.20 & 3.60 \\
\hline & $(7.56-13.93)$ & $(8.23-15.29)$ & $(0.69-2.56)$ & (10.98-18.44) & (9.94-18.74) & $(1.10-6.38)$ \\
\hline \multirow{2}{*}{ Office machinery } & 12.43 & 12.96 & 1.85 & 16.11 & 15.66 & 4.27 \\
\hline & $(9.73-14.57)$ & $(10.97-15.88)$ & $(0.69-3.00)$ & (11.84-20.35) & (11.20-19.47) & $(1.79-6.69)$ \\
\hline \multirow{2}{*}{ Electrical machinery } & 10.77 & 11.98 & 1.46 & 15.02 & 14.51 & 3.75 \\
\hline & $(7.17-14.52)$ & $(8.32-15.20)$ & $(0.69-2.77)$ & (11.24-19.20) & $(9.99-19.34)$ & $(1.39-6.59)$ \\
\hline \multirow{2}{*}{ Radio \& Television } & 11.70 & 12.33 & 1.70 & 15.70 & 15.37 & 4.19 \\
\hline & $(7.74-15.42)$ & $(8.79-15.32)$ & $(0.69-3.00)$ & $(11.60-20.08)$ & $(10.49-20.32)$ & $(1.61-7.02)$ \\
\hline \multirow{2}{*}{$\begin{array}{l}\text { Medical, precision } \\
\text { inst. }\end{array}$} & 11.17 & 11.87 & 1.49 & 15.08 & 14.63 & 3.79 \\
\hline & $(7.85-14.48)$ & $(8.61-14.90)$ & $(0.69-2.77)$ & (11.40-18.76) & $(10.11-19.11)$ & $(1.39-6.44)$ \\
\hline \multirow{2}{*}{ Motor vehicles } & 11.38 & 12.53 & 1.72 & 15.33 & 15.30 & 4.18 \\
\hline & $(8.33-14.29)$ & $(9.81-15.10)$ & $(0.69-2.89)$ & (11.27-19.59) & (10.49-20.34) & $(1.39-7.26)$ \\
\hline & 11.05 & 12.18 & 1.58 & 14.82 & 14.37 & 3.84 \\
\hline insport equipment & $(7.94-14.10)$ & $(1.38-8.28)$ & $(0.69-2.71)$ & $(10.95-19.08)$ & $(9.72-19.40)$ & $(1.10-7.13)$ \\
\hline & 10.24 & 10.96 & 1.28 & 14.07 & 13.38 & 3.39 \\
\hline Furn1 & $(7.18-13.30)$ & $(7.68-14.03)$ & $(0.69-2.56)$ & $(10.32-18.14)$ & $(8.17-18.59)$ & $(1.10-6.10)$ \\
\hline
\end{tabular}

Note: Figures in the parentheses show the ranges for the respective variables; Y, K and L represent log of real gross value added, real fixed capital stock and number of workers respectively. 
Table 6: Impact of Reforms on Technical Efficiency in Indian Manufacturing

Dep. Variable: Absolute Technical Efficiency

\begin{tabular}{|c|c|c|c|c|c|c|c|c|}
\hline Variables & Model 1 & Model 2 & Model 3 & Model 4 & Model 5 & Model 6 & Model 7 & Model 8 \\
\hline Formal & $\begin{array}{l}0.220 * * * \\
(0.00191)\end{array}$ & $\begin{array}{l}0.220 * * * \\
(0.00192)\end{array}$ & $\begin{array}{l}0.230 * * * \\
(0.00192)\end{array}$ & $\begin{array}{l}0.228 * * * \\
(0.00196)\end{array}$ & $\begin{array}{c}-0.175 * * * \\
(0.00401)\end{array}$ & $\begin{array}{c}-0.0746 * * * \\
(0.00456)\end{array}$ & $\begin{array}{l}0.131 * * * \\
(0.00232)\end{array}$ & $\begin{array}{l}0.401 * * * \\
(0.00404)\end{array}$ \\
\hline REFORM & $\begin{array}{c}0.00539 * * * \\
(0.000107)\end{array}$ & & & & $\begin{array}{c}0.00345 * * * \\
(0.000101)\end{array}$ & & & \\
\hline DELICENSE & & $\begin{array}{c}0.00237 * * * \\
(6.38 \mathrm{e}-05)\end{array}$ & & & & $\begin{array}{c}0.00125 * * * \\
(6.03 \mathrm{e}-05)\end{array}$ & & \\
\hline DERESERVE & & & $\begin{array}{c}0.00255 * * * \\
(5.89 \mathrm{e}-05)\end{array}$ & & & & $\begin{array}{c}-0.000126 * * \\
(6.29 \mathrm{e}-05)\end{array}$ & \\
\hline TARIFF & & & & $\begin{array}{c}0.000476 * * * \\
(0.000119)\end{array}$ & & & & $\begin{array}{c}0.00150 * * * \\
(0.000112)\end{array}$ \\
\hline Formal*REFORM & & & & & $\begin{array}{c}0.00736 * * * \\
(6.23 \mathrm{e}-05)\end{array}$ & & & \\
\hline Formal*DELICENSE & & & & & & $\begin{array}{c}0.00349 * * * \\
(5.17 \mathrm{e}-05)\end{array}$ & & \\
\hline Formal*DERESERVE & & & & & & & $\begin{array}{c}0.00411 * * * \\
(4.46 \mathrm{e}-05)\end{array}$ & \\
\hline Formal*TARIFF & & & & & & & & $\begin{array}{c}-0.00365 * * * \\
(7.83 \mathrm{e}-05)\end{array}$ \\
\hline Constant & $\begin{array}{l}0.353 * * * \\
(0.00326)\end{array}$ & $\begin{array}{l}0.373 * * * \\
(0.00314)\end{array}$ & $\begin{array}{l}0.441 * * * \\
(0.00302)\end{array}$ & $\begin{array}{c}0.412 * * * \\
(0.0103)\end{array}$ & $\begin{array}{c}0.556 * * * \\
(0.00338)\end{array}$ & $\begin{array}{l}0.515 * * * \\
(0.00320)\end{array}$ & $\begin{array}{l}0.522 * * * \\
(0.00313) \\
\end{array}$ & $\begin{array}{c}0.406 * * * \\
(0.0101)\end{array}$ \\
\hline Ind. Dummy & Yes & Yes & Yes & Yes & Yes & Yes & Yes & Yes \\
\hline Year Dummy & Yes & Yes & Yes & Yes & Yes & Yes & Yes & Yes \\
\hline $\begin{array}{l}\text { Number of } \\
\text { Observations }\end{array}$ & 174736 & 174736 & 174736 & 174736 & 174736 & 174736 & 174736 & 174736 \\
\hline R-Squared & 0.249 & 0.246 & 0.246 & 0.239 & 0.286 & 0.259 & 0.278 & 0.246 \\
\hline
\end{tabular}




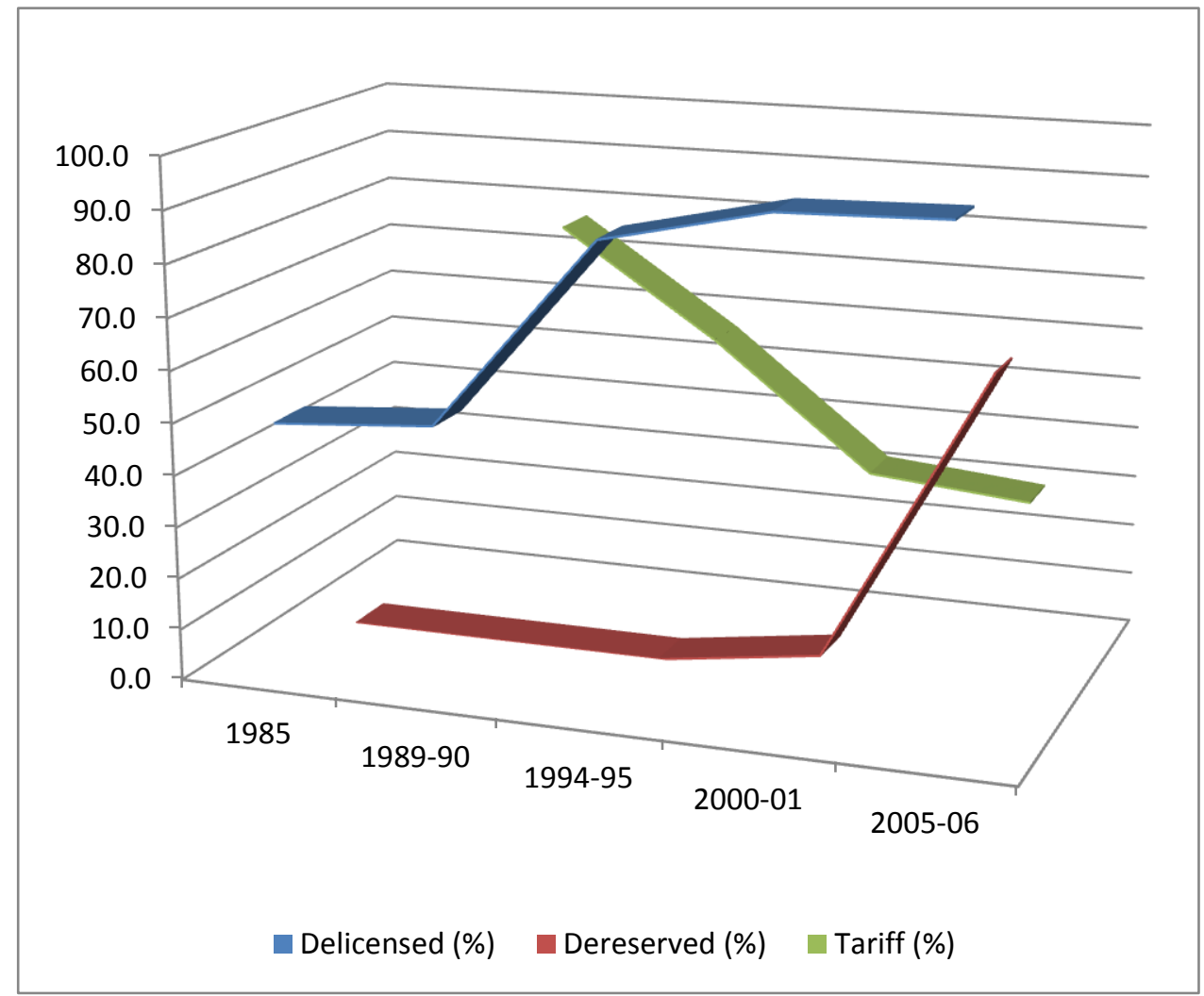

Figure 1: Trend of different Reform variables

Notes: De-licensing indicates percentage of 4 digit industries de-licensed, de-reserved indicates percentage of industries became open to large and medium firms and tariffs represents percentage of import duties levied on an industry. 

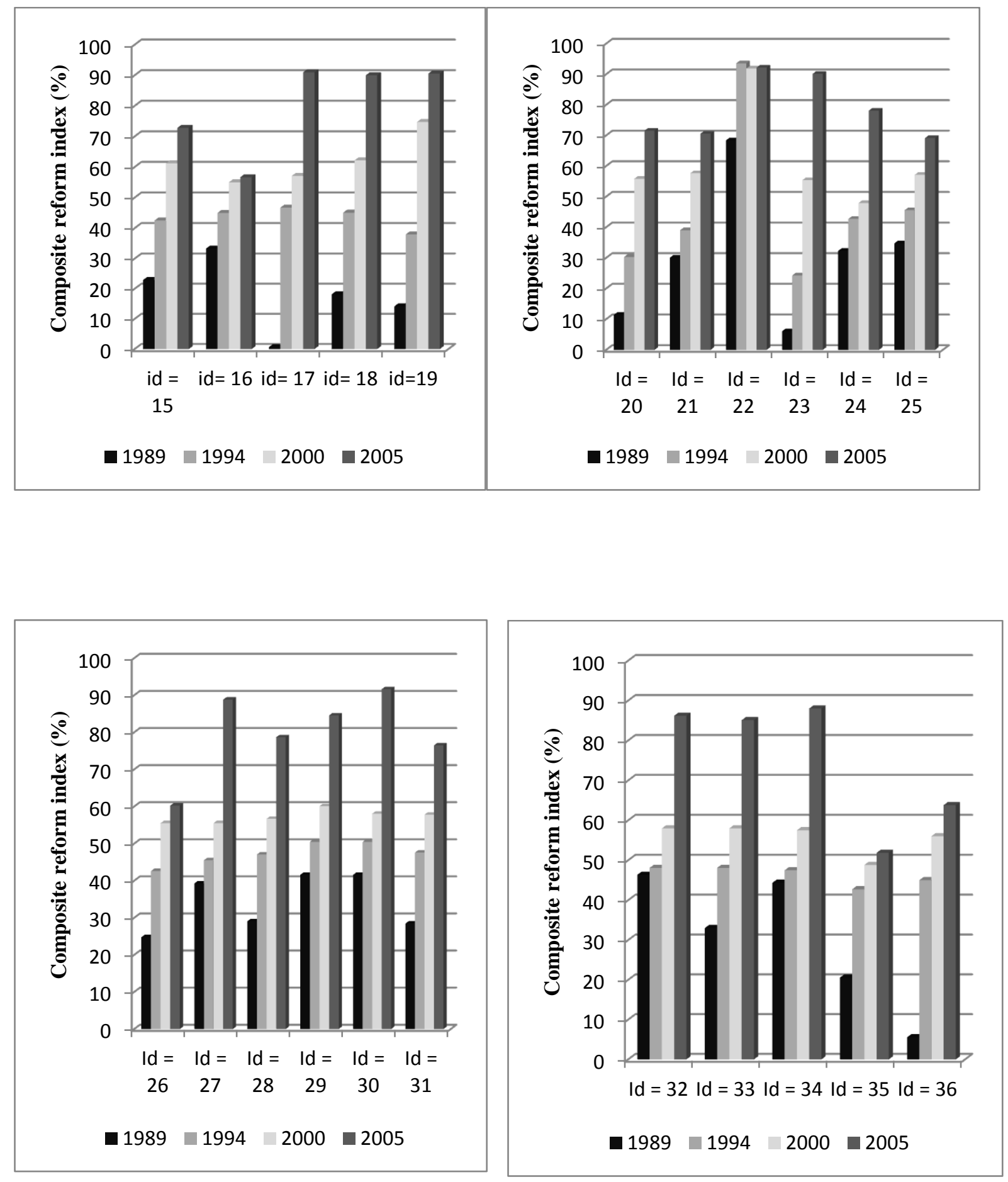

Note: Industry Ids are in Appendix, Table A1.

Figure 2: Industry-wise trend of composite Reform variable (REFORM) 


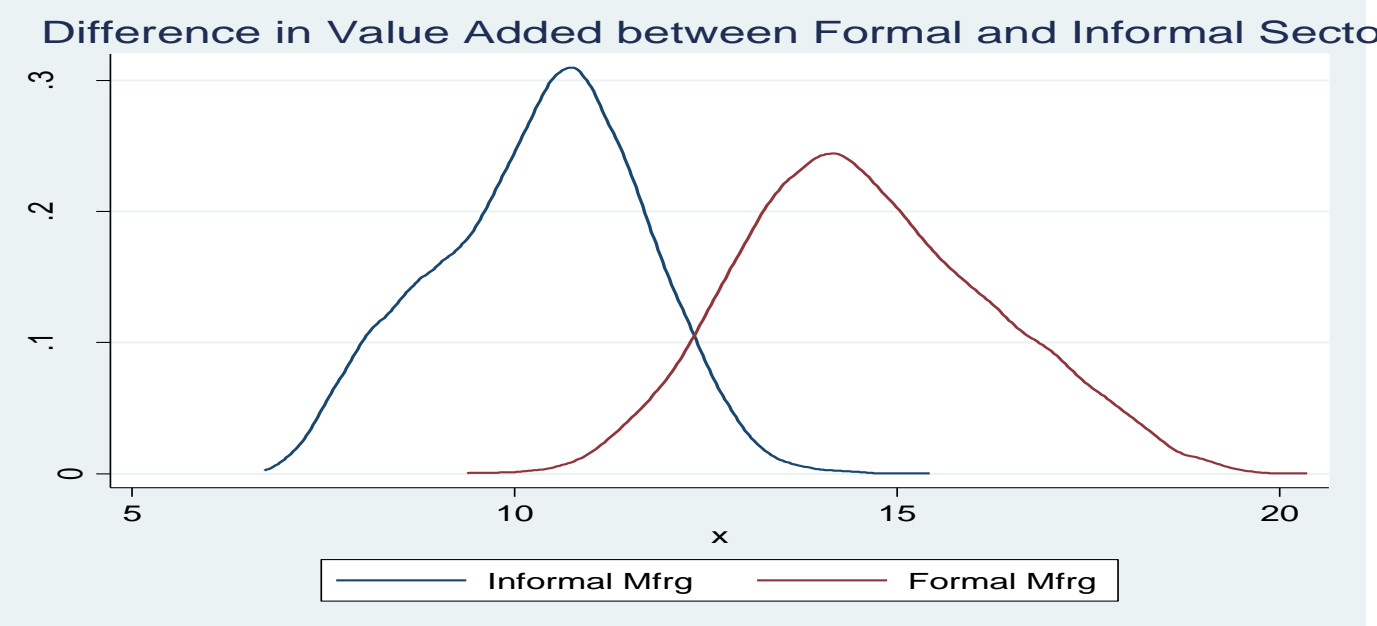

Difference in Capital stock between Formal and Informal Sector
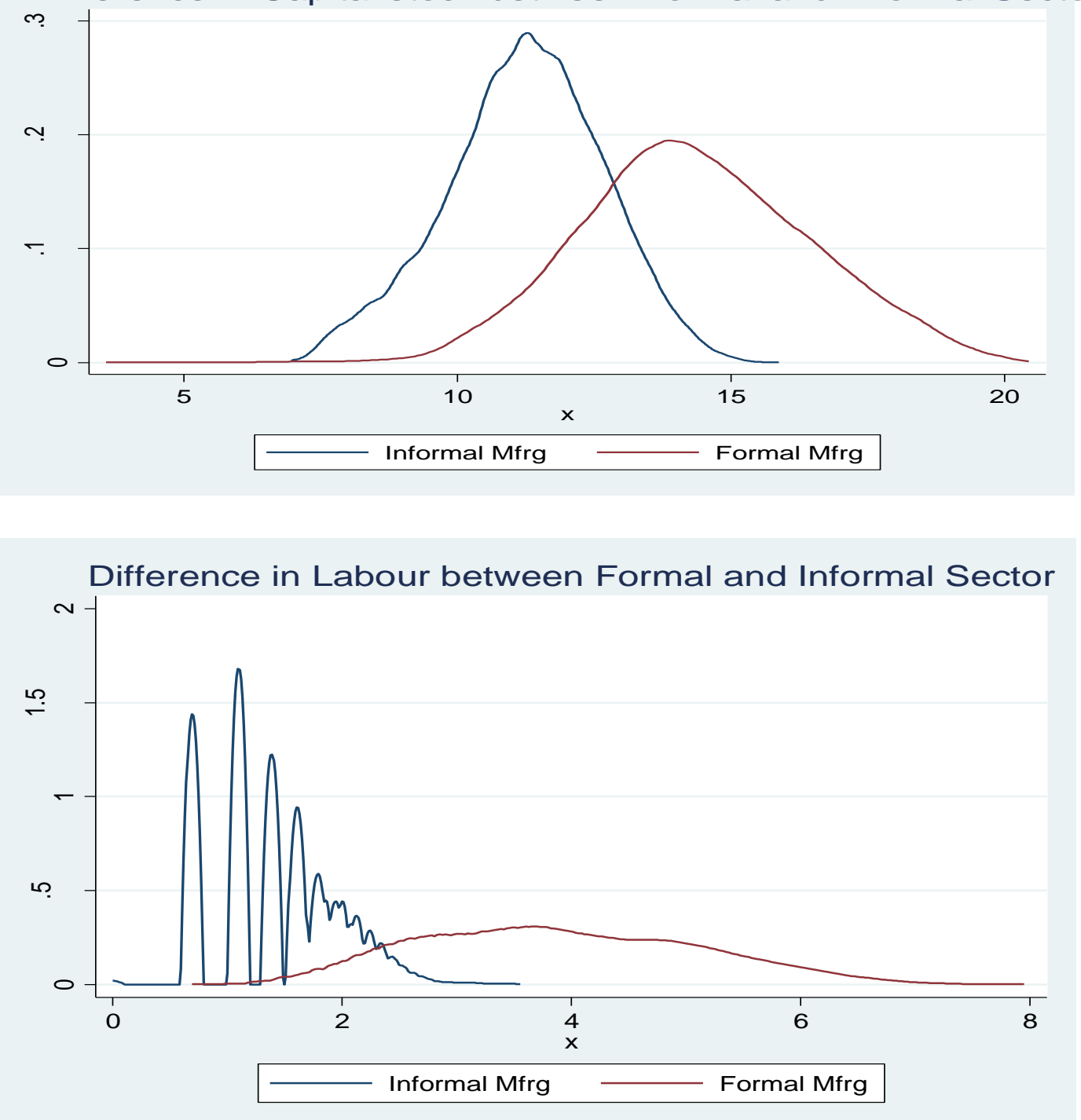

Figure 3:Differences in value added, capital and labour between firms in the informal and formal sectors (averages over the period, 1989-90 to 2005-06, kernel density plots)

Note: Mfrg=Manufacturing 
Figure 4: Year-wise change in Efficiency - Informal Manufacturing versus Formal Manufacturing Firms (Kernel Density Plots)
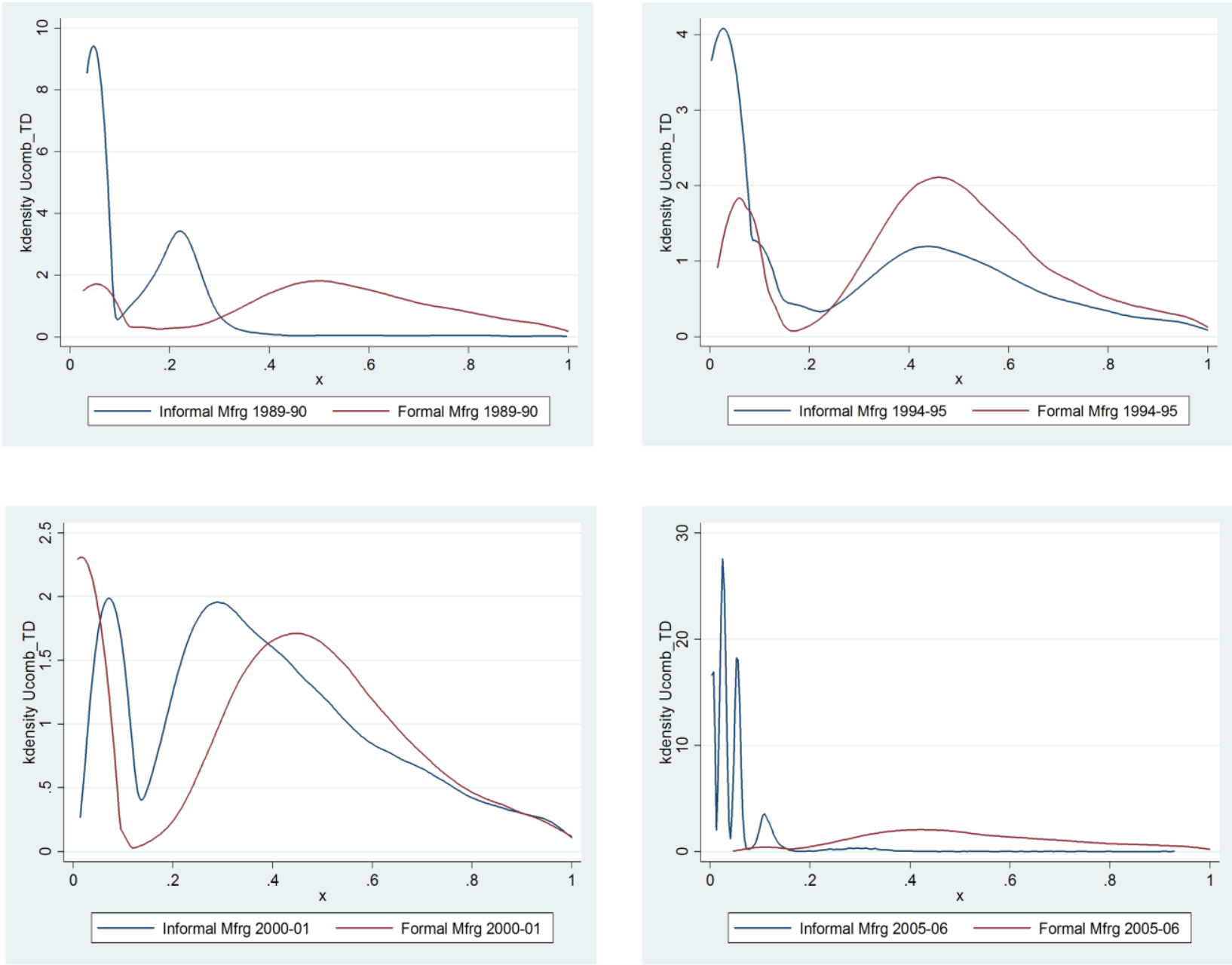


\section{APPENDIX}

\section{TABLE A1: LIST OF INDUSTRIES}

\begin{tabular}{|c|c|c|}
\hline $\begin{array}{l}\text { NIC 2-digit } \\
\text { classification }\end{array}$ & ISIC Code & Description \\
\hline 15 & 311,313 & Manufacture of food products and beverages \\
\hline 16 & 314 & Manufacture of tobacco products \\
\hline 17 & 321 & Manufacture of textiles \\
\hline 18 & 322 & Manufacture of wearing apparel; dressing and dyeing of fur \\
\hline 19 & 323,324 & $\begin{array}{l}\text { Tanning and dressing of leather; manufacture of luggage, } \\
\text { handbags, saddler, harness and footwear }\end{array}$ \\
\hline 20 & 331 & $\begin{array}{l}\text { Manufacture of wood and of products of wood and cork, except } \\
\text { furniture; manufacture of articles of straw and plaiting materials }\end{array}$ \\
\hline 21 & 341 & Manufacture of paper and paper products \\
\hline 22 & 342 & Publishing, printing and reproduction of recorded media \\
\hline 23 & 353,354 & Manufacture of coke, refined petroleum products and nuclear fuel \\
\hline 24 & 351,352 & Manufacture of chemicals and chemical products \\
\hline 25 & 355,356 & Manufacture of rubber and plastics products \\
\hline 26 & $361,362,369$ & Manufacture of other non-metallic mineral products \\
\hline 27 & 371,372 & Manufacture of basic metals \\
\hline 28 & 381 & $\begin{array}{l}\text { Manufacture of fabricated metal products, except machinery and } \\
\text { equipment }\end{array}$ \\
\hline 29 & 382 & Manufacture of machinery and equipment not elsewhere classified \\
\hline 30 & 382 & Manufacture of office, accounting and computing machinery \\
\hline 31 & 383 & $\begin{array}{l}\text { Manufacture of electrical machinery and apparatus not elsewhere } \\
\text { classified }\end{array}$ \\
\hline 32 & 385 & $\begin{array}{l}\text { Manufacture of radio, television and communication equipment } \\
\text { and apparatus }\end{array}$ \\
\hline 33 & 385 & $\begin{array}{l}\text { Manufacture of medical, precision and optical instruments, } \\
\text { watches and clocks }\end{array}$ \\
\hline 34 & 384 & Manufacture of motor vehicles, trailers and semi-trailers \\
\hline 35 & 384 & Manufacture of other transport equipment \\
\hline 36 & 332 & Manufacture of furniture; manufacturing not elsewhere classified \\
\hline
\end{tabular}

Note: Based on National Industrial Classification (NIC) - 1998 (At Two Digit Level) 
Table A2: Estimated production parameters, industry level, 1989-90 and 1994-95 (Formal Firms)

\begin{tabular}{|c|c|c|c|c|c|c|c|c|c|c|c|c|}
\hline \multirow{2}{*}{ Industry } & \multicolumn{6}{|c|}{$1989-90$} & \multicolumn{6}{|c|}{$1994-95$} \\
\hline & Constant & Ln K & Ln L & $\log L$ & Rho & $\mathbf{N}$ & Constant & $\operatorname{Ln~K}$ & $\operatorname{Ln} \mathbf{L}$ & $\log L$ & Rho & $\mathbf{N}$ \\
\hline Food & $\begin{array}{l}5.808 * \\
(0.142)\end{array}$ & $\begin{array}{l}0.365^{*} \\
(0.010)\end{array}$ & $\begin{array}{l}0.844^{*} \\
(0.021)\end{array}$ & -7171.42 & $\begin{array}{l}0.85^{*} \\
(0.03)\end{array}$ & 7743 & $\begin{array}{l}6.417 * \\
(0.100)\end{array}$ & $\begin{array}{l}0.366^{*} \\
(0.007)\end{array}$ & $\begin{array}{l}0.687^{*} \\
(0.013)\end{array}$ & -13627.43 & $\begin{array}{l}0.59 * \\
(0.06)\end{array}$ & 11759 \\
\hline Tobacco & $\begin{array}{l}8.700^{*} \\
(0.770)\end{array}$ & $\begin{array}{l}0.189^{*} \\
(0.018)\end{array}$ & $\begin{array}{l}0.748^{*} \\
(0.046)\end{array}$ & -978.01 & $\begin{array}{l}-0.44 \\
(0.29)\end{array}$ & 863 & $\begin{array}{l}8.209^{*} \\
(0.538)\end{array}$ & $\begin{array}{l}0.236^{*} \\
(0.012)\end{array}$ & $\begin{array}{l}0.754^{*} \\
(0.030)\end{array}$ & -1738.14 & $\begin{array}{l}-0.10 \\
(0.34)\end{array}$ & 1903 \\
\hline Textiles & $\begin{array}{l}5.971 * \\
(0.296)\end{array}$ & $\begin{array}{l}0.321^{*} \\
(0.012)\end{array}$ & $\begin{array}{l}0.805^{*} \\
(0.021)\end{array}$ & -4694.56 & $\begin{array}{l}0.69 * \\
(0.03)\end{array}$ & 6149 & $\begin{array}{l}6.759^{*} \\
(0.097)\end{array}$ & $\begin{array}{l}0.339^{*} \\
(0.008)\end{array}$ & $\begin{array}{l}0.650^{*} \\
(0.013)\end{array}$ & -9891.72 & $\begin{array}{l}0.77 * \\
(0.02)\end{array}$ & 13401 \\
\hline Apparel & $\begin{array}{l}8.613^{*} \\
(0.479)\end{array}$ & $\begin{array}{l}0.444^{*} \\
(0.030)\end{array}$ & $\begin{array}{l}0.446^{*} \\
(0.054)\end{array}$ & -676.18 & $\begin{array}{l}-0.91 * \\
(0.07)\end{array}$ & 589 & $\begin{array}{l}7.507 * \\
(0.303)\end{array}$ & $\begin{array}{l}0.317^{*} \\
(0.022)\end{array}$ & $\begin{array}{l}0.562^{*} \\
(0.034)\end{array}$ & -2307.15 & $\begin{array}{l}0.91 * \\
(0.02)\end{array}$ & 1383 \\
\hline Leather & $\begin{array}{l}7.729 * \\
(0.894)\end{array}$ & $\begin{array}{l}0.292^{*} \\
(0.046)\end{array}$ & $\begin{array}{l}0.710^{*} \\
(0.068)\end{array}$ & -611.40 & $\begin{array}{l}-0.61 * \\
(0.16)\end{array}$ & 642 & $\begin{array}{l}7.418^{*} \\
(0.253)\end{array}$ & $\begin{array}{l}0.274^{*} \\
(0.020)\end{array}$ & $\begin{array}{l}0.811^{*} \\
(0.035)\end{array}$ & -1310.44 & $\begin{array}{l}0.89 * \\
(0.06)\end{array}$ & 1310 \\
\hline Wood & $\begin{array}{l}7.430 * \\
(0.567)\end{array}$ & $\begin{array}{l}0.237 * \\
(0.027)\end{array}$ & $\begin{array}{l}0.662^{*} \\
(0.053)\end{array}$ & -1193.64 & $\begin{array}{l}0.72^{*} \\
(0.07)\end{array}$ & 1858 & $\begin{array}{l}7.488^{*} \\
(0.214)\end{array}$ & $\begin{array}{l}0.251^{*} \\
(0.016)\end{array}$ & $\begin{array}{l}0.705^{*} \\
(0.034)\end{array}$ & -2348.32 & $\begin{array}{l}0.83^{*} \\
(0.09)\end{array}$ & 2664 \\
\hline Paper & $\begin{array}{l}8.069^{*} \\
(0.305)\end{array}$ & $\begin{array}{l}0.331 * \\
(0.026)\end{array}$ & $\begin{array}{l}0.624^{*} \\
(0.050)\end{array}$ & -695.16 & $\begin{array}{l}-0.31 \\
(0.81)\end{array}$ & 605 & $\begin{array}{l}7.883^{*} \\
(0.144)\end{array}$ & $\begin{array}{l}0.325^{*} \\
(0.009)\end{array}$ & $\begin{array}{l}0.762^{*} \\
(0.018)\end{array}$ & -1487.63 & $\begin{array}{c}0.00 \\
(0.67)\end{array}$ & 1097 \\
\hline Publishing & $\begin{array}{l}6.860^{*} \\
(0.209)\end{array}$ & $\begin{array}{l}0.295^{*} \\
(0.018)\end{array}$ & $\begin{array}{l}0.843^{*} \\
(0.040)\end{array}$ & -1406.75 & $\begin{array}{l}0.77^{*} \\
(0.08)\end{array}$ & 1487 & $\begin{array}{l}7.112^{*} \\
(0.184)\end{array}$ & $\begin{array}{l}0.276^{*} \\
(0.013)\end{array}$ & $\begin{array}{l}0.918 * \\
(0.028)\end{array}$ & -1937.49 & $\begin{array}{l}0.77^{*} \\
(0.04)\end{array}$ & 2040 \\
\hline Petroleum & $\begin{array}{l}5.886^{*} \\
(0.645)\end{array}$ & $\begin{array}{l}0.409^{*} \\
(0.045)\end{array}$ & $\begin{array}{l}0.762^{*} \\
(0.077)\end{array}$ & -282.89 & $\begin{array}{l}0.79^{*} \\
(0.38)\end{array}$ & 236 & $\begin{array}{l}4.907 * \\
(0.855)\end{array}$ & $\begin{array}{l}0.510^{*} \\
(0.028)\end{array}$ & $\begin{array}{l}0.641 * \\
(0.044)\end{array}$ & -545.79 & $\begin{array}{c}0.08 \\
(0.46)\end{array}$ & 405 \\
\hline Chemicals & $\begin{array}{l}5.516^{*} \\
(0.203)\end{array}$ & $\begin{array}{l}0.513^{*} \\
(0.014)\end{array}$ & $\begin{array}{l}0.650 * \\
(0.027)\end{array}$ & -2926.11 & $\begin{array}{l}0.77 * \\
(0.07)\end{array}$ & 2129 & $\begin{array}{l}6.117^{*} \\
(0.126)\end{array}$ & $\begin{array}{l}0.452^{*} \\
(0.009)\end{array}$ & $\begin{array}{l}0.664^{*} \\
(0.018)\end{array}$ & -4982.86 & $\begin{array}{l}0.73 * \\
(0.07)\end{array}$ & 3830 \\
\hline Rubber & $\begin{array}{l}7.925^{*} \\
(0.289)\end{array}$ & $\begin{array}{l}0.337^{*} \\
(0.023)\end{array}$ & $\begin{array}{l}0.663^{*} \\
(0.043)\end{array}$ & -1276.70 & $\begin{array}{l}0.54^{*} \\
(0.26)\end{array}$ & 1110 & $\begin{array}{l}6.854^{*} \\
(0.182)\end{array}$ & $\begin{array}{l}0.352^{*} \\
(0.014)\end{array}$ & $\begin{array}{l}0.783^{*} \\
(0.027)\end{array}$ & -2450.94 & $\begin{array}{l}0.76^{*} \\
(0.06)\end{array}$ & 2152 \\
\hline Minerals & $\begin{array}{l}6.692^{*} \\
(0.134)\end{array}$ & $\begin{array}{l}0.314^{*} \\
(0.010)\end{array}$ & $\begin{array}{l}0.776^{*} \\
(0.021)\end{array}$ & -3002.63 & $\begin{array}{l}0.62 * \\
(0.07)\end{array}$ & 2563 & $\begin{array}{l}6.523^{*} \\
(0.105)\end{array}$ & $\begin{array}{l}0.339^{*} \\
(0.008)\end{array}$ & $\begin{array}{l}0.775^{*} \\
(0.017)\end{array}$ & -5348.68 & $\begin{array}{l}0.52^{*} \\
(0.12)\end{array}$ & 4830 \\
\hline $\begin{array}{l}\text { Basic } \\
\text { metal }\end{array}$ & $\begin{array}{l}7.386^{*} \\
(0.200)\end{array}$ & $\begin{array}{l}0.324 * \\
(0.018)\end{array}$ & $\begin{array}{l}0.774^{*} \\
(0.034)\end{array}$ & -1785.63 & $\begin{array}{l}0.54^{*} \\
(0.23)\end{array}$ & 1430 & $\begin{array}{l}6.796^{*} \\
(0.284)\end{array}$ & $\begin{array}{l}0.341^{*} \\
(0.011)\end{array}$ & $\begin{array}{l}0.762 * \\
(0.020)\end{array}$ & -2984.41 & $\begin{array}{l}-0.23 \\
(0.25)\end{array}$ & 2454 \\
\hline $\begin{array}{l}\text { Metal } \\
\text { products }\end{array}$ & $\begin{array}{l}7.367^{*} \\
(0.185)\end{array}$ & $\begin{array}{l}0.237^{*} \\
(0.016)\end{array}$ & $\begin{array}{l}0.915^{*} \\
(0.029)\end{array}$ & -2727.52 & $\begin{array}{l}0.89^{*} \\
(0.02)\end{array}$ & 2987 & $\begin{array}{l}6.480^{*} \\
(0.243)\end{array}$ & $\begin{array}{l}0.301^{*} \\
(0.010)\end{array}$ & $\begin{array}{l}0.835^{*} \\
(0.020)\end{array}$ & -4762.45 & $\begin{array}{l}0.70^{*} \\
(0.04)\end{array}$ & 4989 \\
\hline Machinery & $\begin{array}{l}7.440^{*} \\
(0.172)\end{array}$ & $\begin{array}{l}0.304 * \\
(0.014)\end{array}$ & $\begin{array}{l}0.883^{*} \\
(0.025)\end{array}$ & -2865.96 & $\begin{array}{l}-0.23 \\
(0.24)\end{array}$ & 2773 & $\begin{array}{l}7.513^{*} \\
(0.220)\end{array}$ & $\begin{array}{l}0.302^{*} \\
(0.010)\end{array}$ & $\begin{array}{l}0.825^{*} \\
(0.018)\end{array}$ & -4628.69 & $\begin{array}{l}-0.63^{*} \\
(0.03)\end{array}$ & 4405 \\
\hline $\begin{array}{l}\text { Office } \\
\text { machinery }\end{array}$ & $\begin{array}{l}7.037^{*} \\
(1.020)\end{array}$ & $\begin{array}{l}0.321 * \\
(0.084)\end{array}$ & $\begin{array}{l}1.078^{*} \\
(0.116)\end{array}$ & -81.01 & $\begin{array}{l}-0.08 \\
(2.98)\end{array}$ & 72 & $\begin{array}{l}6.164^{*} \\
(1.471)\end{array}$ & $\begin{array}{l}0.479^{*} \\
(0.096)\end{array}$ & $\begin{array}{l}0.700^{*} \\
(0.137)\end{array}$ & -160.21 & $\begin{array}{l}-0.03 \\
(1.29)\end{array}$ & 105 \\
\hline $\begin{array}{l}\text { Electrical } \\
\text { machinery }\end{array}$ & $\begin{array}{l}6.980^{*} \\
(0.303)\end{array}$ & $\begin{array}{l}0.348^{*} \\
(0.025)\end{array}$ & $\begin{array}{l}0.859^{*} \\
(0.043)\end{array}$ & -1068.22 & $\begin{array}{l}0.62 * \\
(0.10)\end{array}$ & 904 & $\begin{array}{l}6.789 * \\
(0.373)\end{array}$ & $\begin{array}{l}0.307^{*} \\
(0.017)\end{array}$ & $\begin{array}{l}0.890^{*} \\
(0.030)\end{array}$ & -1892.94 & $\begin{array}{l}0.73^{*} \\
(0.04)\end{array}$ & 1557 \\
\hline $\begin{array}{l}\text { Radio \& } \\
\text { Television }\end{array}$ & $\begin{array}{l}7.278^{*} \\
(0.680)\end{array}$ & $\begin{array}{l}0.343^{*} \\
(0.058)\end{array}$ & $\begin{array}{l}0.733^{*} \\
(0.091)\end{array}$ & -285.61 & $\begin{array}{c}0.82 \\
(0.59)\end{array}$ & 230 & $\begin{array}{l}6.923^{*} \\
(0.715)\end{array}$ & $\begin{array}{l}0.340^{*} \\
(0.032)\end{array}$ & $\begin{array}{l}0.820^{*} \\
(0.071)\end{array}$ & -745.67 & $\begin{array}{c}0.21 \\
(0.38)\end{array}$ & 541 \\
\hline $\begin{array}{l}\text { Medical, } \\
\text { precision } \\
\text { inst. }\end{array}$ & $\begin{array}{l}8.590^{*} \\
(0.646)\end{array}$ & $\begin{array}{l}0.260^{*} \\
(0.053)\end{array}$ & $\begin{array}{l}0.812^{*} \\
(0.096)\end{array}$ & -286.90 & $\begin{array}{l}-0.58 * \\
(0.27)\end{array}$ & 249 & $\begin{array}{l}8.708^{*} \\
(0.186)\end{array}$ & $\begin{array}{l}0.302^{*} \\
(0.014)\end{array}$ & $\begin{array}{l}0.795^{*} \\
(0.025)\end{array}$ & -592.62 & $\begin{array}{c}0.00 \\
(0.69)\end{array}$ & 397 \\
\hline $\begin{array}{l}\text { Motor } \\
\text { vehicles }\end{array}$ & $\begin{array}{l}6.161^{*} \\
(0.677)\end{array}$ & $\begin{array}{l}0.341^{*} \\
(0.027)\end{array}$ & $\begin{array}{l}0.862 * \\
(0.042)\end{array}$ & -402.05 & $\begin{array}{l}0.63^{*} \\
(0.29)\end{array}$ & 351 & $\begin{array}{l}7.157^{*} \\
(0.244)\end{array}$ & $\begin{array}{l}0.314^{*} \\
(0.019)\end{array}$ & $\begin{array}{l}0.851^{*} \\
(0.030)\end{array}$ & -844.19 & $\begin{array}{l}0.75 * \\
(0.15)\end{array}$ & 800 \\
\hline $\begin{array}{l}\text { Transport } \\
\text { equipment }\end{array}$ & $\begin{array}{l}8.315^{*} \\
(0.671)\end{array}$ & $\begin{array}{l}0.223^{*} \\
(0.028)\end{array}$ & $\begin{array}{l}0.865^{*} \\
(0.043)\end{array}$ & -644.31 & $\begin{array}{l}-0.40 \\
(0.27)\end{array}$ & 545 & $\begin{array}{l}7.624 * \\
(0.230)\end{array}$ & $\begin{array}{l}0.290^{*} \\
(0.016)\end{array}$ & $\begin{array}{l}0.818^{*} \\
(0.025)\end{array}$ & -1334.53 & $\begin{array}{l}0.76^{*} \\
(0.12)\end{array}$ & 1194 \\
\hline Furniture & $\begin{array}{l}8.166^{*} \\
(0.653)\end{array}$ & $\begin{array}{l}0.285^{*} \\
(0.026)\end{array}$ & $\begin{array}{l}0.851^{*} \\
(0.054)\end{array}$ & -1361.14 & $\begin{array}{l}-0.76^{*} \\
(0.06)\end{array}$ & 2808 & $\begin{array}{l}5.550^{*} \\
(0.462)\end{array}$ & $\begin{array}{l}0.273^{*} \\
(0.017)\end{array}$ & $\begin{array}{l}0.877 * \\
(0.037)\end{array}$ & -2347.16 & $\begin{array}{l}0.88^{*} \\
(0.02)\end{array}$ & 3763 \\
\hline
\end{tabular}

Notes:a) Ln K and ln L are natural logarithms of capital stock and labour respectively; b) Log L is the value of the $\log$ likelihood function, Rho is selection parameter; and $\mathrm{N}$ is the total number of firms; $\mathrm{d}$ ) * indicates level of significance at 10 per cent; e) Figures in parenthesis are standard errors. 
Table A3: Estimated production parameters, industry level, 2000-01 and 2005-06 (Formal Firms)

\begin{tabular}{|c|c|c|c|c|c|c|c|c|c|c|c|c|}
\hline \multirow{2}{*}{ Industry } & \multicolumn{6}{|c|}{ 2000-01 } & \multicolumn{6}{|c|}{ 2005-06 } \\
\hline & Constant & $\operatorname{Ln~K}$ & $\operatorname{Ln~L~}$ & $\log L$ & Rho & $\mathbf{N}$ & Constant & Ln K & $\operatorname{Ln} \mathbf{L}$ & $\log L$ & Rho & $\mathbf{N}$ \\
\hline Food & $\begin{array}{l}6.017 * \\
(0.218)\end{array}$ & $\begin{array}{l}0.408^{*} \\
(0.008)\end{array}$ & $\begin{array}{l}0.641 * \\
(0.013)\end{array}$ & -8231.82 & $\begin{array}{l}-0.04 \\
(0.13)\end{array}$ & 10325 & $\begin{array}{l}8.923^{*} \\
(0.080)\end{array}$ & $\begin{array}{l}0.333^{*} \\
(0.006)\end{array}$ & $\begin{array}{l}0.641^{*} \\
(0.010)\end{array}$ & -10932.01 & $\begin{array}{l}-0.83^{*} \\
(0.02)\end{array}$ & 9151 \\
\hline Tobacco & $\begin{array}{l}7.330 * \\
(0.813)\end{array}$ & $\begin{array}{l}0.248^{*} \\
(0.018)\end{array}$ & $\begin{array}{l}0.826^{*} \\
(0.034)\end{array}$ & -753.40 & $\begin{array}{c}0.15 \\
(0.35)\end{array}$ & 940 & $\begin{array}{l}6.903^{*} \\
(0.515)\end{array}$ & $\begin{array}{l}0.268^{*} \\
(0.013)\end{array}$ & $\begin{array}{l}0.884^{*} \\
(0.025)\end{array}$ & -1252.06 & $\begin{array}{c}0.21 \\
(0.26)\end{array}$ & 743 \\
\hline Textiles & $\begin{array}{l}7.723^{*} \\
(0.213)\end{array}$ & $\begin{array}{l}0.377^{*} \\
(0.008)\end{array}$ & $\begin{array}{l}0.593^{*} \\
(0.014)\end{array}$ & -5932.74 & $\begin{array}{l}-0.84 * \\
(0.01)\end{array}$ & 10130 & $\begin{array}{l}8.304 * \\
(0.085)\end{array}$ & $\begin{array}{l}0.383^{*} \\
(0.006)\end{array}$ & $\begin{array}{l}0.620^{*} \\
(0.010)\end{array}$ & -7618.19 & $\begin{array}{l}-0.82 * \\
(0.02)\end{array}$ & 5458 \\
\hline Apparel & $\begin{array}{l}7.935^{*} \\
(0.294)\end{array}$ & $\begin{array}{l}0.317 * \\
(0.019)\end{array}$ & $\begin{array}{l}0.624 * \\
(0.028)\end{array}$ & -1994.19 & $\begin{array}{l}0.56^{*} \\
(0.09)\end{array}$ & 6352 & $\begin{array}{l}8.263 * \\
(0.231)\end{array}$ & $\begin{array}{l}0.264^{*} \\
(0.015)\end{array}$ & $\begin{array}{l}0.651^{*} \\
(0.021)\end{array}$ & -2501.24 & $\begin{array}{l}0.72^{*} \\
(0.05)\end{array}$ & 3996 \\
\hline Leather & $\begin{array}{l}7.840^{*} \\
(0.369)\end{array}$ & $\begin{array}{l}0.252 * \\
(0.030)\end{array}$ & $\begin{array}{c}0.835^{*} \\
(0.04)\end{array}$ & -726.26 & $\begin{array}{l}0.83^{*} \\
(0.10)\end{array}$ & 1212 & $\begin{array}{l}7.089 * \\
(0.522)\end{array}$ & $\begin{array}{l}0.367 * \\
(0.022)\end{array}$ & $\begin{array}{l}0.539 * \\
(0.028)\end{array}$ & -999.95 & $\begin{array}{l}0.54^{*} \\
(0.10)\end{array}$ & 871 \\
\hline Wood & $\begin{array}{l}7.002 * \\
(0.267)\end{array}$ & $\begin{array}{l}0.278^{*} \\
(0.022)\end{array}$ & $\begin{array}{l}0.808^{*} \\
(0.059)\end{array}$ & -1164.49 & $\begin{array}{l}0.82 * \\
(0.14)\end{array}$ & 3107 & $\begin{array}{l}7.730^{*} \\
(0.363)\end{array}$ & $\begin{array}{l}0.294 * \\
(0.014)\end{array}$ & $\begin{array}{l}0.757 * \\
(0.043)\end{array}$ & -1473.31 & $\begin{array}{c}0.05 \\
(0.44)\end{array}$ & 1771 \\
\hline Paper & $\begin{array}{l}7.484^{*} \\
(0.270)\end{array}$ & $\begin{array}{l}0.338^{*} \\
(0.023)\end{array}$ & $\begin{array}{l}0.701 * \\
(0.040)\end{array}$ & -768.04 & $\begin{array}{c}0.34 \\
(0.26)\end{array}$ & 964 & $\begin{array}{l}7.667 * \\
(0.206)\end{array}$ & $\begin{array}{l}0.361 * \\
(0.018)\end{array}$ & $\begin{array}{l}0.653 * \\
(0.033)\end{array}$ & -1071.70 & $\begin{array}{l}0.52^{*} \\
(0.15)\end{array}$ & 1026 \\
\hline Publishing & $\begin{array}{l}5.600 * \\
(0.524)\end{array}$ & $\begin{array}{l}0.347 * \\
(0.020)\end{array}$ & $\begin{array}{l}0.824 * \\
(0.041)\end{array}$ & -1084.30 & $\begin{array}{l}0.80^{*} \\
(0.04)\end{array}$ & 2200 & $\begin{array}{l}7.653^{*} \\
(0.191)\end{array}$ & $\begin{array}{l}0.348^{*} \\
(0.013)\end{array}$ & $\begin{array}{l}0.795^{*} \\
(0.029)\end{array}$ & -1470.96 & $\begin{array}{l}-0.76^{*} \\
(0.06)\end{array}$ & 1395 \\
\hline Petroleum & $\begin{array}{l}5.258 * \\
(0.055)\end{array}$ & $\begin{array}{l}0.601 * \\
(0.004)\end{array}$ & $\begin{array}{l}0.502 * \\
(0.005)\end{array}$ & -544.59 & $\begin{array}{c}0.00 \\
(0.38)\end{array}$ & 249 & $\begin{array}{l}4.898^{*} \\
(0.100)\end{array}$ & $\begin{array}{l}0.430 * \\
(0.032)\end{array}$ & $\begin{array}{l}0.965^{*} \\
(0.059)\end{array}$ & -427.89 & $\begin{array}{l}-0.56^{*} \\
(0.24)\end{array}$ & 316 \\
\hline Chemicals & $\begin{array}{l}6.625^{*} \\
(0.204)\end{array}$ & $\begin{array}{l}0.423^{*} \\
(0.014)\end{array}$ & $\begin{array}{l}0.634 * \\
(0.022)\end{array}$ & -3143.34 & $\begin{array}{c}0.15 \\
(0.55)\end{array}$ & 2665 & $\begin{array}{l}7.452^{*} \\
(0.146)\end{array}$ & $\begin{array}{l}0.393^{*} \\
(0.011)\end{array}$ & $\begin{array}{c}0.602 * \\
(0.02)\end{array}$ & -3886.18 & $\begin{array}{c}0.38 \\
(0.25)\end{array}$ & 3025 \\
\hline Rubber & $\begin{array}{l}6.706^{*} \\
(0.241)\end{array}$ & $\begin{array}{l}0.407 * \\
(0.019)\end{array}$ & $\begin{array}{l}0.661 * \\
(0.033)\end{array}$ & -1290.51 & $\begin{array}{l}0.63^{*} \\
(0.17)\end{array}$ & 1741 & $\begin{array}{l}8.730^{*} \\
(0.153)\end{array}$ & $\begin{array}{l}0.304 * \\
(0.012)\end{array}$ & $\begin{array}{l}0.755^{*} \\
(0.022)\end{array}$ & -2039.85 & $\begin{array}{l}-0.71 * \\
(0.06)\end{array}$ & 1845 \\
\hline Minerals & $\begin{array}{l}6.030^{*} \\
(0.156)\end{array}$ & $\begin{array}{l}0.400 * \\
(0.010)\end{array}$ & $\begin{array}{l}0.731^{*} \\
(0.018)\end{array}$ & -3036.94 & $\begin{array}{c}0.14 \\
(0.18)\end{array}$ & 4265 & $\begin{array}{l}6.620^{*} \\
(0.212)\end{array}$ & $\begin{array}{l}0.372^{*} \\
(0.008)\end{array}$ & $\begin{array}{l}0.801 * \\
(0.015)\end{array}$ & -5449.42 & $\begin{array}{l}-0.38 * \\
(0.08)\end{array}$ & 4976 \\
\hline $\begin{array}{l}\text { Basic } \\
\text { metal }\end{array}$ & $\begin{array}{l}7.384 * \\
(0.184)\end{array}$ & $\begin{array}{l}0.355^{*} \\
(0.016)\end{array}$ & $\begin{array}{l}0.720^{*} \\
(0.028)\end{array}$ & -1588.03 & $\begin{array}{l}-0.56^{*} \\
(0.17)\end{array}$ & 1620 & $\begin{array}{l}7.907 * \\
(0.168)\end{array}$ & $\begin{array}{l}0.350^{*} \\
(0.014)\end{array}$ & $\begin{array}{l}0.709 * \\
(0.025)\end{array}$ & -2530.83 & $\begin{array}{c}0.30 \\
(0.29)\end{array}$ & 2090 \\
\hline $\begin{array}{l}\text { Metal } \\
\text { products }\end{array}$ & $\begin{array}{c}7.899 * \\
(0.328)\end{array}$ & $\begin{array}{l}0.321 * \\
(0.014)\end{array}$ & $\begin{array}{l}0.784 * \\
(0.026)\end{array}$ & -2418.52 & $\begin{array}{l}-0.80^{*} \\
(0.03)\end{array}$ & 5326 & $\begin{array}{l}7.527 * \\
(0.152)\end{array}$ & $\begin{array}{l}0.345^{*} \\
(0.013)\end{array}$ & $\begin{array}{l}0.651^{*} \\
(0.019)\end{array}$ & -3737.72 & $\begin{array}{l}0.63^{*} \\
(0.06)\end{array}$ & 3844 \\
\hline Machinery & $\begin{array}{l}7.587^{*} \\
(0.287)\end{array}$ & $\begin{array}{l}0.312 * \\
(0.012)\end{array}$ & $\begin{array}{l}0.816^{*} \\
(0.020)\end{array}$ & -2611.61 & $\begin{array}{l}-0.74 * \\
(0.03)\end{array}$ & 3349 & $\begin{array}{l}8.255^{*} \\
(0.133)\end{array}$ & $\begin{array}{l}0.287 * \\
(0.011)\end{array}$ & $\begin{array}{l}0.873^{*} \\
(0.019)\end{array}$ & -3336.02 & $\begin{array}{l}-0.57 * \\
(0.06)\end{array}$ & 3044 \\
\hline $\begin{array}{l}\text { Office } \\
\text { machinery }\end{array}$ & $\begin{array}{l}6.011^{*} \\
(1.718)\end{array}$ & $\begin{array}{l}0.547 * \\
(0.134)\end{array}$ & $\begin{array}{l}0.524 * \\
(0.157)\end{array}$ & -66.45 & $\begin{array}{c}0.79 \\
(1.10)\end{array}$ & 60 & $\begin{array}{l}10.623 * \\
(1.798)\end{array}$ & $\begin{array}{c}0.145 \\
(0.179)\end{array}$ & $\begin{array}{l}1.042 * \\
(0.304)\end{array}$ & -65.26 & $\begin{array}{c}0.82 \\
(1.59)\end{array}$ & 57 \\
\hline $\begin{array}{l}\text { Electrical } \\
\text { machinery }\end{array}$ & $\begin{array}{l}7.548^{*} \\
(0.229)\end{array}$ & $\begin{array}{l}0.340 * \\
(0.020)\end{array}$ & $\begin{array}{l}0.788^{*} \\
(0.033)\end{array}$ & -1252.96 & $\begin{array}{l}0.83^{*} \\
(0.08)\end{array}$ & 1274 & $\begin{array}{l}9.164^{*} \\
(0.185)\end{array}$ & $\begin{array}{l}0.276^{*} \\
(0.014)\end{array}$ & $\begin{array}{l}0.853^{*} \\
(0.026)\end{array}$ & -1561.77 & $\begin{array}{l}-0.67 * \\
(0.09)\end{array}$ & 1546 \\
\hline $\begin{array}{l}\text { Radio \& } \\
\text { Television }\end{array}$ & $\begin{array}{l}7.068^{*} \\
(0.415)\end{array}$ & $\begin{array}{l}0.399 * \\
(0.036)\end{array}$ & $\begin{array}{l}0.751^{*} \\
(0.060)\end{array}$ & -312.63 & $\begin{array}{l}0.90^{*} \\
(0.26)\end{array}$ & 304 & $\begin{array}{l}9.879^{*} \\
(1.146)\end{array}$ & $\begin{array}{l}0.219^{*} \\
(0.052)\end{array}$ & $\begin{array}{l}0.753^{*} \\
(0.085)\end{array}$ & -348.40 & $\begin{array}{c}0.36 \\
(0.49)\end{array}$ & 278 \\
\hline $\begin{array}{l}\text { Medical, } \\
\text { precision } \\
\text { inst. }\end{array}$ & $\begin{array}{l}7.894 * \\
(0.739)\end{array}$ & $\begin{array}{l}0.293 * \\
(0.034)\end{array}$ & $\begin{array}{l}0.770^{*} \\
(0.056)\end{array}$ & -427.91 & $\begin{array}{c}0.19 \\
(0.31)\end{array}$ & 410 & $\begin{array}{l}9.300^{*} \\
(0.542)\end{array}$ & $\begin{array}{l}0.286^{*} \\
(0.043)\end{array}$ & $\begin{array}{l}0.695^{*} \\
(0.072)\end{array}$ & -458.34 & $\begin{array}{c}0.42 \\
(0.48)\end{array}$ & 371 \\
\hline $\begin{array}{l}\text { Motor } \\
\text { vehicles }\end{array}$ & $\begin{array}{l}6.912 * \\
(0.222)\end{array}$ & $\begin{array}{l}0.360 * \\
(0.018)\end{array}$ & $\begin{array}{l}0.775 * \\
(0.032)\end{array}$ & -818.84 & $\begin{array}{l}0.69 * \\
(0.17)\end{array}$ & 979 & $\begin{array}{l}7.874^{*} \\
(0.253)\end{array}$ & $\begin{array}{l}0.343^{*} \\
(0.020)\end{array}$ & $\begin{array}{l}0.723^{*} \\
(0.033)\end{array}$ & -1193.76 & $\begin{array}{l}-0.51^{*} \\
(0.13)\end{array}$ & 1032 \\
\hline $\begin{array}{l}\text { Transport } \\
\text { equipment }\end{array}$ & $\begin{array}{l}7.251 * \\
(0.556)\end{array}$ & $\begin{array}{l}0.352 * \\
(0.028)\end{array}$ & $\begin{array}{l}0.710 * \\
(0.044)\end{array}$ & -643.72 & $\begin{array}{l}-0.67 * \\
(0.08)\end{array}$ & 729 & $\begin{array}{l}7.885^{*} \\
(0.213)\end{array}$ & $\begin{array}{l}0.366^{*} \\
(0.019)\end{array}$ & $\begin{array}{l}0.650 * \\
(0.027)\end{array}$ & -772.57 & $\begin{array}{l}-0.40 \\
(0.33)\end{array}$ & 773 \\
\hline Furniture & $\begin{array}{l}6.514 * \\
(0.359) \\
\end{array}$ & $\begin{array}{l}0.285^{*} \\
(0.021)\end{array}$ & $\begin{array}{l}0.962 * \\
(0.038)\end{array}$ & -1308.77 & $\begin{array}{l}0.93 * \\
(0.07)\end{array}$ & 5044 & $\begin{array}{l}8.256^{*} \\
(0.261)\end{array}$ & $\begin{array}{l}0.229^{*} \\
(0.016)\end{array}$ & $\begin{array}{l}0.883^{*} \\
(0.031)\end{array}$ & -1937.96 & $\begin{array}{l}0.70^{*} \\
(0.10)\end{array}$ & 3228 \\
\hline
\end{tabular}

Notes:a) Ln K and ln L are natural logarithms of capital stock and labour respectively; b) Log L is the value of the $\log$ likelihood function, Rho is selection parameter; and $\mathrm{N}$ is the total number of firms; d) * indicates level of significance at 10 per cent; e) Figures in parenthesis are standard errors. 
Table A4: Estimated production parameters, industry level, 1989-90 and 1994-95 (Informal Firms)

\begin{tabular}{|c|c|c|c|c|c|c|c|c|c|c|c|c|}
\hline \multirow{2}{*}{ Industry } & \multicolumn{6}{|c|}{$1989-90$} & \multicolumn{6}{|c|}{ 1994-95 } \\
\hline & Constant & Ln K & $\operatorname{Ln} \mathbf{L}$ & $\log L$ & Rho & $\mathbf{N}$ & Constant & Ln K & $\operatorname{Ln} \mathbf{L}$ & $\log L$ & Rho & $\mathbf{N}$ \\
\hline Food & $\begin{array}{l}8.333^{*} \\
(0.267)\end{array}$ & $\begin{array}{l}0.161 * \\
(0.012)\end{array}$ & $\begin{array}{l}0.205^{*} \\
(0.051)\end{array}$ & -9225.05 & $\begin{array}{l}-0.66^{*} \\
(0.06)\end{array}$ & 7743 & $\begin{array}{l}7.006^{*} \\
(0.125)\end{array}$ & $\begin{array}{l}0.332 * \\
(0.010)\end{array}$ & $\begin{array}{l}0.471 * \\
(0.023)\end{array}$ & -9923.65 & $\begin{array}{l}-0.58 * \\
(0.07)\end{array}$ & 11759 \\
\hline Tobacco & $\begin{array}{l}7.524^{*} \\
(0.771)\end{array}$ & $\begin{array}{c}0.032 \\
(0.033)\end{array}$ & $\begin{array}{c}0.101 \\
(0.134)\end{array}$ & -841.76 & $\begin{array}{l}0.86^{*} \\
(0.06)\end{array}$ & 863 & $\begin{array}{l}8.323^{*} \\
(0.509)\end{array}$ & $\begin{array}{l}0.060^{*} \\
(0.027)\end{array}$ & $\begin{array}{l}0.119^{*} \\
(0.032)\end{array}$ & -2115.01 & $\begin{array}{l}0.61^{*} \\
(0.15)\end{array}$ & 1903 \\
\hline Textiles & $\begin{array}{l}7.819^{*} \\
(0.265)\end{array}$ & $\begin{array}{l}0.174^{*} \\
(0.011)\end{array}$ & $\begin{array}{l}0.222^{*} \\
(0.050)\end{array}$ & -7528.45 & $\begin{array}{l}-0.46^{*} \\
(0.14)\end{array}$ & 6149 & $\begin{array}{l}5.843^{*} \\
(0.095)\end{array}$ & $\begin{array}{l}0.341^{*} \\
(0.005)\end{array}$ & $\begin{array}{l}0.762 * \\
(0.014)\end{array}$ & -12386.74 & $\begin{array}{l}-0.80 * \\
(0.01)\end{array}$ & 13401 \\
\hline Apparel & $\begin{array}{l}7.514^{*} \\
(0.829)\end{array}$ & $\begin{array}{l}0.311^{*} \\
(0.069)\end{array}$ & $\begin{array}{c}0.326 \\
(0.226)\end{array}$ & -562.36 & $\begin{array}{l}-0.72 * \\
(0.26)\end{array}$ & 589 & $\begin{array}{l}8.408^{*} \\
(0.385)\end{array}$ & $\begin{array}{l}0.183^{*} \\
(0.039)\end{array}$ & $\begin{array}{l}0.805^{*} \\
(0.106)\end{array}$ & -555.65 & $\begin{array}{l}-0.58^{*} \\
(0.31)\end{array}$ & 1383 \\
\hline Leather & $\begin{array}{l}8.031^{*} \\
(0.927)\end{array}$ & $\begin{array}{l}0.170^{*} \\
(0.043)\end{array}$ & $\begin{array}{l}0.193^{*} \\
(0.192)\end{array}$ & -671.61 & $\begin{array}{l}-0.23 \\
(0.26)\end{array}$ & 642 & $\begin{array}{l}6.733^{*} \\
(0.372)\end{array}$ & $\begin{array}{l}0.330 * \\
(0.033)\end{array}$ & $\begin{array}{l}0.738^{*} \\
(0.080)\end{array}$ & -1102.02 & $\begin{array}{l}0.82 * \\
(0.12)\end{array}$ & 1310 \\
\hline Wood & $\begin{array}{l}7.536^{*} \\
(0.535)\end{array}$ & $\begin{array}{l}0.153^{*} \\
(0.021)\end{array}$ & $\begin{array}{l}0.332^{*} \\
(0.089)\end{array}$ & -2474.93 & $\begin{array}{c}0.28 \\
(0.48)\end{array}$ & 1858 & $\begin{array}{l}7.873 * \\
(0.261)\end{array}$ & $\begin{array}{l}0.213^{*} \\
(0.012)\end{array}$ & $\begin{array}{l}0.814^{*} \\
(0.041)\end{array}$ & -2284.69 & $\begin{array}{c}0.07 \\
(1.00)\end{array}$ & 2664 \\
\hline Paper & $\begin{array}{l}8.771^{*} \\
(2.105)\end{array}$ & $\begin{array}{l}-0.000 \\
(0.081)\end{array}$ & $\begin{array}{l}0.771^{*} \\
(0.345)\end{array}$ & -332.45 & $\begin{array}{c}0.45 \\
(0.63)\end{array}$ & 605 & $\begin{array}{l}5.708 * \\
(0.943)\end{array}$ & $\begin{array}{l}0.330 * \\
(0.049)\end{array}$ & $\begin{array}{l}0.993^{*} \\
(0.116)\end{array}$ & -415.37 & $\begin{array}{l}-0.30 \\
(0.30)\end{array}$ & 1097 \\
\hline Publishing & $\begin{array}{l}7.619^{*} \\
(0.780)\end{array}$ & $\begin{array}{l}0.180^{*} \\
(0.033)\end{array}$ & $\begin{array}{l}0.318^{*} \\
(0.134)\end{array}$ & -1523.19 & $\begin{array}{l}-0.39 \\
(0.36)\end{array}$ & 1487 & $\begin{array}{l}7.472 * \\
(0.356)\end{array}$ & $\begin{array}{l}0.265^{*} \\
(0.022)\end{array}$ & $\begin{array}{l}0.764^{*} \\
(0.054)\end{array}$ & -1606.60 & $\begin{array}{l}-0.86^{*} \\
(0.02)\end{array}$ & 2040 \\
\hline Petroleum & $\begin{array}{l}8.582 * \\
(4.0710\end{array}$ & $\begin{array}{l}-0.080 \\
(0.1600\end{array}$ & $\begin{array}{l}-0.187 \\
(0.810)\end{array}$ & -139.35 & $\begin{array}{l}0.84 * \\
(0.12)\end{array}$ & 236 & $\begin{array}{l}6.624 * \\
(1.139)\end{array}$ & $\begin{array}{c}0.317 * \\
(0.0780\end{array}$ & $\begin{array}{l}0.709^{*} \\
(0.301)\end{array}$ & -131.95 & $\begin{array}{c}0.05 \\
(0.73)\end{array}$ & 405 \\
\hline Chemicals & $\begin{array}{l}4.976 * \\
(1.298)\end{array}$ & $\begin{array}{l}0.225^{*} \\
(0.059)\end{array}$ & $\begin{array}{l}0.514^{*} \\
(0.223)\end{array}$ & -899.17 & $\begin{array}{l}0.80 * \\
(0.09)\end{array}$ & 2129 & $\begin{array}{l}7.169^{*} \\
(0.625)\end{array}$ & $\begin{array}{l}0.444^{*} \\
(0.031)\end{array}$ & $\begin{array}{l}0.685^{*} \\
(0.081)\end{array}$ & -1684.90 & $\begin{array}{l}-0.93^{*} \\
(0.02)\end{array}$ & 3830 \\
\hline Rubber & $\begin{array}{l}8.603 * \\
(1.358)\end{array}$ & $\begin{array}{l}0.145^{*} \\
(0.057)\end{array}$ & $\begin{array}{l}0.499 * \\
(0.237)\end{array}$ & -830.70 & $\begin{array}{l}-0.41 \\
(0.26)\end{array}$ & 1110 & $\begin{array}{l}6.404 * \\
(0.354)\end{array}$ & $\begin{array}{l}0.334^{*} \\
(0.028)\end{array}$ & $\begin{array}{l}0.892^{*} \\
(0.078)\end{array}$ & -1301.74 & $\begin{array}{c}0.08 \\
(0.33)\end{array}$ & 2152 \\
\hline Minerals & $\begin{array}{l}7.302^{*} \\
(0.574)\end{array}$ & $\begin{array}{l}0.095^{*} \\
(0.031)\end{array}$ & $\begin{array}{c}0.083 \\
(0.126)\end{array}$ & -1506.18 & $\begin{array}{l}0.76^{*} \\
(0.08)\end{array}$ & 2563 & $\begin{array}{l}6.431^{*} \\
(0.223)\end{array}$ & $\begin{array}{l}0.344^{*} \\
(0.015)\end{array}$ & $\begin{array}{l}0.635^{*} \\
(0.035)\end{array}$ & -3327.46 & $\begin{array}{c}0.11 \\
(0.22)\end{array}$ & 4830 \\
\hline $\begin{array}{l}\text { Basic } \\
\text { metal }\end{array}$ & $\begin{array}{l}10.347 * \\
(2.378)\end{array}$ & $\begin{array}{c}0.003 \\
(0.087)\end{array}$ & $\begin{array}{l}1.307^{*} \\
(0.371)\end{array}$ & -596.80 & $\begin{array}{l}-0.76^{*} \\
(0.24)\end{array}$ & 1430 & $\begin{array}{l}8.944^{*} \\
(0.679)\end{array}$ & $\begin{array}{l}0.217^{*} \\
(0.036)\end{array}$ & $\begin{array}{l}0.942 * \\
(0.128)\end{array}$ & -741.87 & $\begin{array}{l}-0.79 * \\
(0.13)\end{array}$ & 2454 \\
\hline $\begin{array}{l}\text { Metal } \\
\text { products }\end{array}$ & $\begin{array}{l}6.309^{*} \\
(0.448)\end{array}$ & $\begin{array}{l}0.209^{*} \\
(0.023)\end{array}$ & $\begin{array}{l}0.386^{*} \\
(0.085)\end{array}$ & -3270.97 & $\begin{array}{l}0.75^{*} \\
(0.07)\end{array}$ & 2987 & $\begin{array}{l}7.178^{*} \\
(0.206)\end{array}$ & $\begin{array}{l}0.276^{*} \\
(0.011)\end{array}$ & $\begin{array}{l}0.853^{*} \\
(0.029)\end{array}$ & -4018.47 & $\begin{array}{l}-0.86^{*} \\
(0.01)\end{array}$ & 4989 \\
\hline Machinery & $\begin{array}{l}9.030^{*} \\
(0.545)\end{array}$ & $\begin{array}{l}0.134^{*} \\
(0.027)\end{array}$ & $\begin{array}{l}0.518^{*} \\
(0.103)\end{array}$ & -2395.61 & $\begin{array}{l}-0.81^{*} \\
(0.05)\end{array}$ & 2773 & $\begin{array}{l}6.997 * \\
(0.217)\end{array}$ & $\begin{array}{l}0.276^{*} \\
(0.016)\end{array}$ & $\begin{array}{l}1.014 * \\
(0.041)\end{array}$ & -3023.78 & $\begin{array}{l}-0.12 \\
(0.24)\end{array}$ & 4405 \\
\hline $\begin{array}{l}\text { Office } \\
\text { machinery }\end{array}$ & $\begin{array}{l}9.492^{*} \\
(0.017)\end{array}$ & $\begin{array}{l}0.312^{*} \\
(0.004)\end{array}$ & $\begin{array}{c}-0.167^{*} \\
(0.018)\end{array}$ & -12.39 & $\begin{array}{c}-0.67 \\
(1.89)\end{array}$ & 72 & $\begin{array}{c}16.141 * \\
(0.816)\end{array}$ & $\begin{array}{c}-0.311^{*} \\
(0.048)\end{array}$ & $\begin{array}{l}0.803^{*} \\
(0.072)\end{array}$ & -10.65 & $\begin{array}{c}0.62 \\
(51.47)\end{array}$ & 105 \\
\hline $\begin{array}{l}\text { Electrical } \\
\text { machinery }\end{array}$ & $\begin{array}{l}8.154^{*} \\
(1.710)\end{array}$ & $\begin{array}{l}0.158^{*} \\
(0.063)\end{array}$ & $\begin{array}{c}0.259 \\
(0.240)\end{array}$ & -549.53 & $\begin{array}{l}-0.07 \\
(0.50)\end{array}$ & 904 & $\begin{array}{l}7.453^{*} \\
(0.437)\end{array}$ & $\begin{array}{l}0.245^{*} \\
(0.035)\end{array}$ & $\begin{array}{l}1.056^{*} \\
(0.085)\end{array}$ & -739.18 & $\begin{array}{l}-0.16 \\
(0.43)\end{array}$ & 1557 \\
\hline $\begin{array}{l}\text { Radio \& } \\
\text { Television }\end{array}$ & $\begin{array}{l}11.193 * \\
(1.673)\end{array}$ & $\begin{array}{l}-0.014 \\
(0.102)\end{array}$ & $\begin{array}{c}0.582 \\
(0.525)\end{array}$ & -111.20 & $\begin{array}{l}-0.99^{*} \\
(0.06)\end{array}$ & 230 & $\begin{array}{l}7.643^{*} \\
(1.062)\end{array}$ & $\begin{array}{l}0.315^{*} \\
(0.088)\end{array}$ & $\begin{array}{l}1.052^{*} \\
(0.152)\end{array}$ & -113.55 & $\begin{array}{l}-0.99 * \\
(0.01)\end{array}$ & 541 \\
\hline $\begin{array}{l}\text { Medical, } \\
\text { precision } \\
\text { inst. }\end{array}$ & $\begin{array}{c}12.230 * \\
(0.406)\end{array}$ & $\begin{array}{c}-0.098^{*} \\
(0.028)\end{array}$ & $\begin{array}{l}0.868^{*} \\
(0.130)\end{array}$ & -142.55 & $\begin{array}{l}-0.99 * \\
(0.06)\end{array}$ & 249 & $\begin{array}{l}6.123^{*} \\
(2.258)\end{array}$ & $\begin{array}{l}0.329 * \\
(0.120)\end{array}$ & $\begin{array}{l}1.087^{*} \\
(0.284)\end{array}$ & -167.18 & $\begin{array}{l}-0.25 \\
(0.48)\end{array}$ & 397 \\
\hline $\begin{array}{l}\text { Motor } \\
\text { vehicles }\end{array}$ & $\begin{array}{l}27.659 * \\
(10.128)\end{array}$ & $\begin{array}{c}-0.890 \\
(1.011)\end{array}$ & $\begin{array}{c}0.071 \\
(2.910)\end{array}$ & -90.39 & $\begin{array}{l}-0.99 * \\
(0.02)\end{array}$ & 351 & $\begin{array}{l}6.920 * \\
(0.425)\end{array}$ & $\begin{array}{l}0.404 * \\
(0.038)\end{array}$ & $\begin{array}{c}0.753^{*} \\
(0.094)\end{array}$ & -272.54 & $\begin{array}{l}-0.99 * \\
(0.00)\end{array}$ & 800 \\
\hline $\begin{array}{l}\text { Transport } \\
\text { equipment }\end{array}$ & $\begin{array}{l}9.850^{*} \\
(1.284)\end{array}$ & $\begin{array}{l}0.146^{*} \\
(0.061)\end{array}$ & $\begin{array}{c}0.284 \\
(0.246)\end{array}$ & -374.48 & $\begin{array}{l}-0.86^{*} \\
(0.11)\end{array}$ & 545 & $\begin{array}{l}8.222 * \\
(0.713)\end{array}$ & $\begin{array}{l}0.231^{*} \\
(0.050)\end{array}$ & $\begin{array}{l}0.906^{*} \\
(0.106)\end{array}$ & -722.02 & $\begin{array}{l}-0.54 \\
(0.47)\end{array}$ & 1194 \\
\hline Furniture & $\begin{array}{l}7.218^{*} \\
(0.332)\end{array}$ & $\begin{array}{c}0.179 * \\
(0.016)\end{array}$ & $\begin{array}{l}0.567 * \\
(0.067)\end{array}$ & -3795.77 & $\begin{array}{l}-0.36 \\
(0.29)\end{array}$ & 2808 & $\begin{array}{l}7.881^{*} \\
(0.104)\end{array}$ & $\begin{array}{l}0.218^{*} \\
(0.010)\end{array}$ & $\begin{array}{c}0.821 * \\
(0.026)\end{array}$ & -3303.74 & $\begin{array}{l}-0.40 * \\
(0.22)\end{array}$ & 3763 \\
\hline
\end{tabular}

Notes:a) Ln K and ln L are natural logarithms of capital stock and labour respectively; b) Log L is the value of the $\log$ likelihood function, Rho is selection parameter; and $\mathrm{N}$ is the total number of firms; $\mathrm{d}$ ) * indicates level of significance at 10 per cent; e) Figures in parenthesis are standard errors. 
Table A5: Estimated production parameters, industry level, 2000-01 and 2005-06 (Informal Firms)

\begin{tabular}{|c|c|c|c|c|c|c|c|c|c|c|c|c|}
\hline \multirow{2}{*}{ Industry } & \multicolumn{6}{|c|}{$2000-01$} & \multicolumn{6}{|c|}{ 2005-06 } \\
\hline & Constant & Ln K & $\operatorname{Ln} \mathbf{L}$ & $\log L$ & Rho & $\mathbf{N}$ & Constant & $\operatorname{Ln} K$ & $\operatorname{Ln} \mathbf{L}$ & $\log L$ & Rho & $\mathbf{N}$ \\
\hline \multirow{2}{*}{ Food } & $6.992 *$ & $0.336^{*}$ & $0.610^{*}$ & \multirow[t]{2}{*}{-11165.70} & $-0.55^{*}$ & \multirow[t]{2}{*}{10325} & $4.257^{*}$ & $0.258 *$ & $1.314^{*}$ & \multirow[t]{2}{*}{-6878.01} & $-0.25 *$ & \multirow[t]{2}{*}{9151} \\
\hline & $(0.10)$ & $(0.008)$ & (0.018) & & $(0.07)$ & & $(0.247)$ & $(0.013)$ & $(0.030)$ & & $(0.11)$ & \\
\hline \multirow{2}{*}{ Tobacco } & $7.698^{*}$ & $0.294^{*}$ & $0.452^{*}$ & \multirow[t]{2}{*}{-1092.17} & $-0.79 *$ & \multirow[t]{2}{*}{940} & $4.374 *$ & $0.330 *$ & $0.640^{*}$ & \multirow[t]{2}{*}{-156.30} & -0.40 & \multirow[t]{2}{*}{743} \\
\hline & (0.368) & $(0.034)$ & $(0.056)$ & & $(0.12)$ & & (1.026) & $(0.072)$ & (0.183) & & $(0.64)$ & \\
\hline \multirow{2}{*}{ Textiles } & $5.940^{*}$ & $0.372^{*}$ & $0.766^{*}$ & \multirow[t]{2}{*}{-9303.53} & $-0.84 *$ & \multirow[t]{2}{*}{10130} & $3.837^{*}$ & $0.334 *$ & $0.762^{*}$ & \multirow[t]{2}{*}{-2560.01} & -0.13 & \multirow[t]{2}{*}{5458} \\
\hline & (0.103) & $(0.005)$ & (0.014) & & $(0.01)$ & & $(0.252)$ & (0.013) & $(0.035)$ & & $(0.26)$ & \\
\hline \multirow{2}{*}{ Apparel } & $7.191^{*}$ & $0.269^{*}$ & $0.944 *$ & \multirow[t]{2}{*}{-5884.64} & $-0.32 *$ & 6352 & $4.018^{*}$ & $0.275^{*}$ & $0.943^{*}$ & -3242.74 & -0.19 & 3996 \\
\hline & $(0.085)$ & $(0.008)$ & $(0.018)$ & & $(0.08)$ & & (0.193) & (0.010) & $(0.025)$ & & $(0.12)$ & \\
\hline Leather & $8.335^{*}$ & $0.163^{*}$ & $0.914 *$ & -1114.95 & 0.13 & 1212 & $4.066^{*}$ & $0.326^{*}$ & $0.890^{*}$ & -500.40 & -0.26 & 871 \\
\hline Leanner & $(0.186)$ & $(0.017)$ & $(0.047)$ & & $(0.16)$ & & $(0.695)$ & $(0.038)$ & (0.093) & & $(0.23)$ & \\
\hline & $7.965^{*}$ & $0.195^{*}$ & $0.871^{*}$ & -2776.73 & 0.29 & 3107 & $5.633^{*}$ & $0.094 *$ & $1.256^{*}$ & -1463.26 & $0.89 *$ & 1771 \\
\hline Wood & $(0.092)$ & $(0.007)$ & $(0.025)$ & & $(0.27)$ & & $(0.274)$ & $(0.015)$ & $(0.045)$ & & $(0.02)$ & \\
\hline Paner & $6.691 *$ & $0.385^{*}$ & $0.625^{*}$ & -798.48 & $-0.74 *$ & 964 & 0.593 & $0.647 *$ & $1.645^{*}$ & -591.51 & $-0.66^{*}$ & 1026 \\
\hline Paper & $(0.248)$ & $(0.022)$ & (0.059) & & $(0.07)$ & & (1.947) & $(0.120)$ & $(0.248)$ & & $(0.18)$ & \\
\hline Publishing & $5.848^{*}$ & $0.341^{*}$ & $0.799 *$ & -2082.75 & $-0.78^{*}$ & 2200 & $4.151^{*}$ & $0.247 *$ & $1.305^{*}$ & -1218.42 & -0.28 & 1395 \\
\hline Publisning & $(0.244)$ & $(0.014)$ & (0.029) & & $(0.03)$ & & $(0.671)$ & $(0.034)$ & $(0.075)$ & & $(0.27)$ & \\
\hline Petr & $7.440^{*}$ & $0.264^{*}$ & $0.724 *$ & -113.61 & $0.99 *$ & 249 & 0.719 & $0.427 *$ & $1.646^{*}$ & -137.78 & 0.24 & 316 \\
\hline Petr & $(0.238)$ & $(0.027)$ & (0.089) & & $(0.00)$ & & (3.933) & $(0.179)$ & $(0.542)$ & & $(0.59)$ & \\
\hline icals & $4.464^{*}$ & $0.491^{*}$ & $0.503^{*}$ & -1967.33 & $0.88^{*}$ & 2665 & 0.730 & $0.694^{*}$ & $1.108^{*}$ & -1765.69 & -0.42 & 3025 \\
\hline Chemicals & $(0.329)$ & $(0.024)$ & $(0.062)$ & & $(0.06)$ & & (1.501) & $(0.051)$ & $(0.126)$ & & $(0.45)$ & \\
\hline Rubber & $6.313^{*}$ & $0.417 *$ & $0.770^{*}$ & -1677.38 & $-0.79^{*}$ & 1741 & $1.831^{*}$ & $0.467 *$ & $1.765^{*}$ & -1367.39 & $-0.40 *$ & 1845 \\
\hline Rubber & $(0.195)$ & $(0.017)$ & (0.040) & & $(0.04)$ & & (1.108) & $(0.051)$ & $(0.136)$ & & $(0.20)$ & \\
\hline & $6.839^{*}$ & $0.315^{*}$ & $0.578^{*}$ & -4754.30 & $0.68^{*}$ & 4265 & $5.226^{*}$ & $0.253^{*}$ & $0.868^{*}$ & -4235.81 & -0.22 & 4976 \\
\hline Minerals & $(0.126)$ & $(0.010)$ & $(0.025)$ & & $(0.07)$ & & $(0.461)$ & $(0.020)$ & $(0.048)$ & & $(0.16)$ & \\
\hline Basic & $7.059^{*}$ & $0.341^{*}$ & $0.804 *$ & -1150.88 & $-0.60^{*}$ & 1620 & $2.854^{*}$ & $0.393^{*}$ & $1.641^{*}$ & -923.80 & -0.32 & 2090 \\
\hline metal & $(0.320)$ & $(0.022)$ & (0.065) & & $(0.25)$ & & (1.527) & (0.069) & $(0.207)$ & & $(0.41)$ & \\
\hline Metal & $7.568^{*}$ & $0.241^{*}$ & $0.866^{*}$ & -4782.16 & 0.21 & 5326 & $4.318^{*}$ & $0.284^{*}$ & $1.122^{*}$ & -3301.92 & -0.16 & 3844 \\
\hline products & (0.087) & $(0.007)$ & (0.018) & & $(0.15)$ & & (0.319) & $(0.016)$ & $(0.040)$ & & $(0.25)$ & \\
\hline & $7.298^{*}$ & $0.298^{*}$ & $0.989^{*}$ & -2910.03 & $-0.84 *$ & 3349 & $2.983^{*}$ & $0.351 *$ & $1.864^{*}$ & -1918.32 & $-0.35^{*}$ & 3044 \\
\hline Machinery & (0.148) & $(0.013)$ & $(0.027)$ & & $(0.05)$ & & $(0.661)$ & $(0.036)$ & $(0.090)$ & & $(0.20)$ & \\
\hline Office & $12.832 *$ & -0.176 & $2.125^{*}$ & -27.40 & $-0.99 *$ & 60 & $12.280 *$ & $-0.237 *$ & $2.449^{*}$ & -35.63 & $-0.99 *$ & 57 \\
\hline machiner & (4.148) & $(0.312)$ & $(0.542)$ & & $(0.07)$ & & & $(0.021)$ & $(0.034)$ & & $(0.05)$ & \\
\hline Electrical & $6.444 *$ & $0.372^{*}$ & $0.799 *$ & -1008.77 & $-0.46^{*}$ & 1274 & $4.401^{*}$ & $0.319 *$ & $1.916^{*}$ & -1591.90 & $-0.73 *$ & 1546 \\
\hline machinery & $(0.390)$ & $(0.027)$ & $(0.061)$ & & $(0.17)$ & & (0.819) & $(0.042)$ & (0.108) & & $(0.09)$ & \\
\hline Radio \& & $5.957^{*}$ & $0.411^{*}$ & $0.624 *$ & -145.99 & 0.25 & 304 & 4.172 & 0.294 & $2.869^{*}$ & -135.29 & -0.41 & 278 \\
\hline Television & (1.814) & $(0.108)$ & $(0.250)$ & & $(0.74)$ & & (2.879) & $(0.214)$ & $(0.556)$ & & $(0.57)$ & \\
\hline Medical, & $6.842^{*}$ & $0.324^{*}$ & $0.787^{*}$ & -265.88 & $0.69 *$ & 410 & $1.741 *$ & $0.554^{*}$ & $1.560^{*}$ & -205.81 & -0.39 & 371 \\
\hline $\begin{array}{l}\text { precision } \\
\text { inst. }\end{array}$ & $(0.705)$ & $(0.066)$ & $(0.133)$ & & $(0.28)$ & & (2.697) & $(0.144)$ & $(0.417)$ & & $(0.43)$ & \\
\hline Motor & $7.048^{*}$ & $0.276^{*}$ & $0.940^{*}$ & -808.07 & -0.39 & 979 & $5.067 *$ & $0.269 *$ & $1.794 *$ & -461.98 & -0.61 & 1032 \\
\hline vehicles & $(0.552)$ & $(0.032)$ & (0.063) & & $(0.44)$ & & $(2.412)$ & $(0.078)$ & $(0.277)$ & & $(0.56)$ & \\
\hline Transport & $7.187^{*}$ & $0.301^{*}$ & $0.851^{*}$ & -511.38 & -0.56 & 729 & $2.334^{*}$ & $0.292 *$ & $0.951^{*}$ & -446.85 & $0.98 *$ & 773 \\
\hline equipment & $(0.547)$ & $(0.032)$ & $(0.087)$ & & $(0.39)$ & & (1.084) & $(0.072)$ & $(0.154)$ & & $(0.01)$ & \\
\hline & $7.520^{*}$ & $0.240^{*}$ & $0.857^{*}$ & -4338.43 & $-0.75^{*}$ & 5044 & $4.646^{*}$ & $0.244^{*}$ & $1.027^{*}$ & -3127.69 & $0.89 *$ & 3228 \\
\hline ture & $(0.118)$ & $(0.001)$ & $(0.017)$ & & $(0.03)$ & & $(0.188)$ & $(0.011)$ & $(0.027)$ & & $(0.01)$ & \\
\hline
\end{tabular}

Notes:a) Ln K and ln L are natural logarithms of capital stock and labour respectively; b) Log L is the value of the $\log$ likelihood function, Rho is selection parameter; and $\mathrm{N}$ is the total number of firms; $\mathrm{d}$ ) * indicates level of significance at 10 per cent; e) Figures in parenthesis are standard errors. 
Figure A1: Kernel Density Plots of Efficiency in Informal Firms - Comparison of Two Different Ways to Estimate Selection Equation (Pooled versus year by year selection)

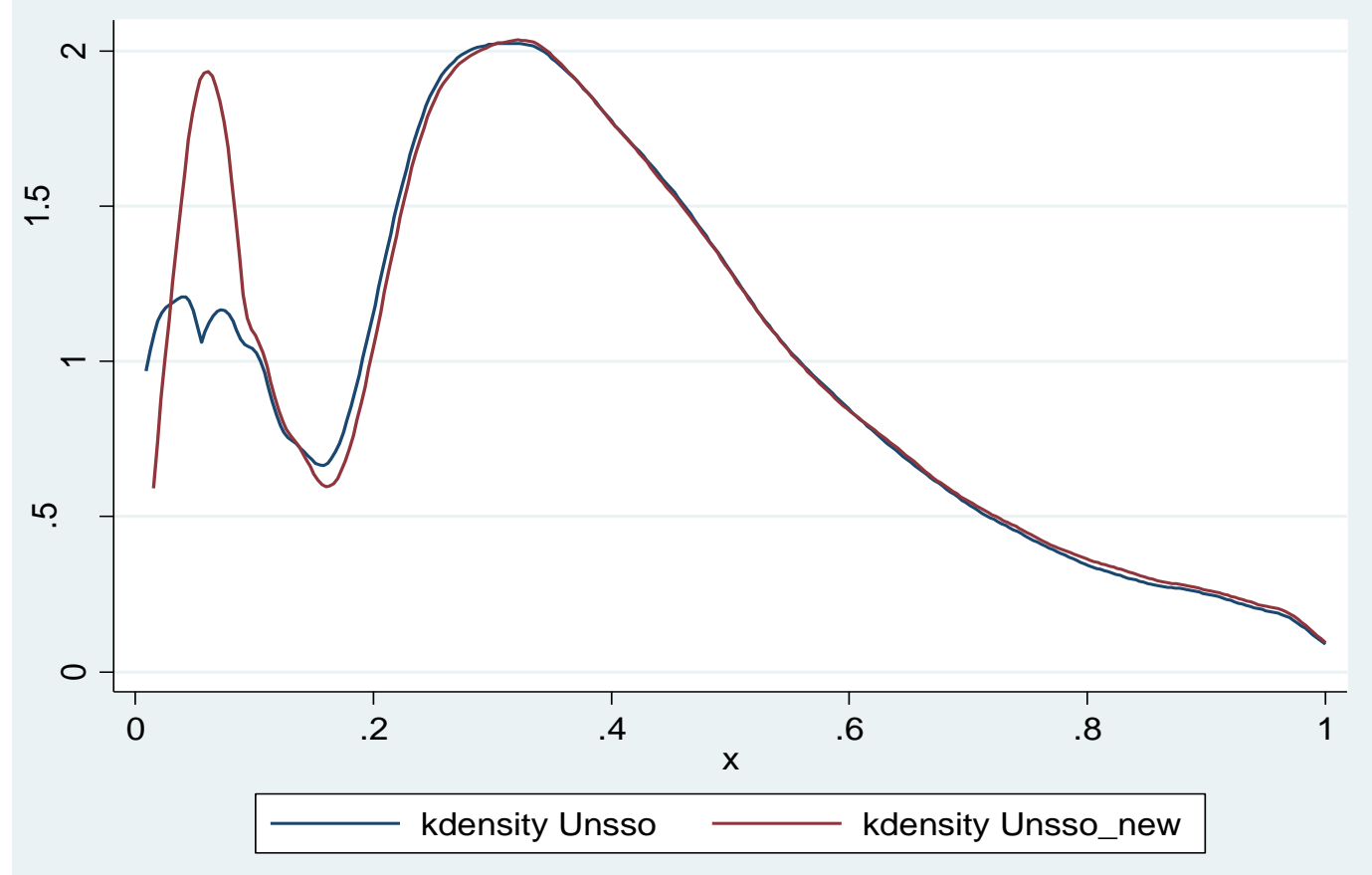

Figure A2: Kernel Density Plots of Efficiency in Formal Firms - Comparison of Two Different Ways to Estimate Selection Equation (Pooled versus year by year selection)

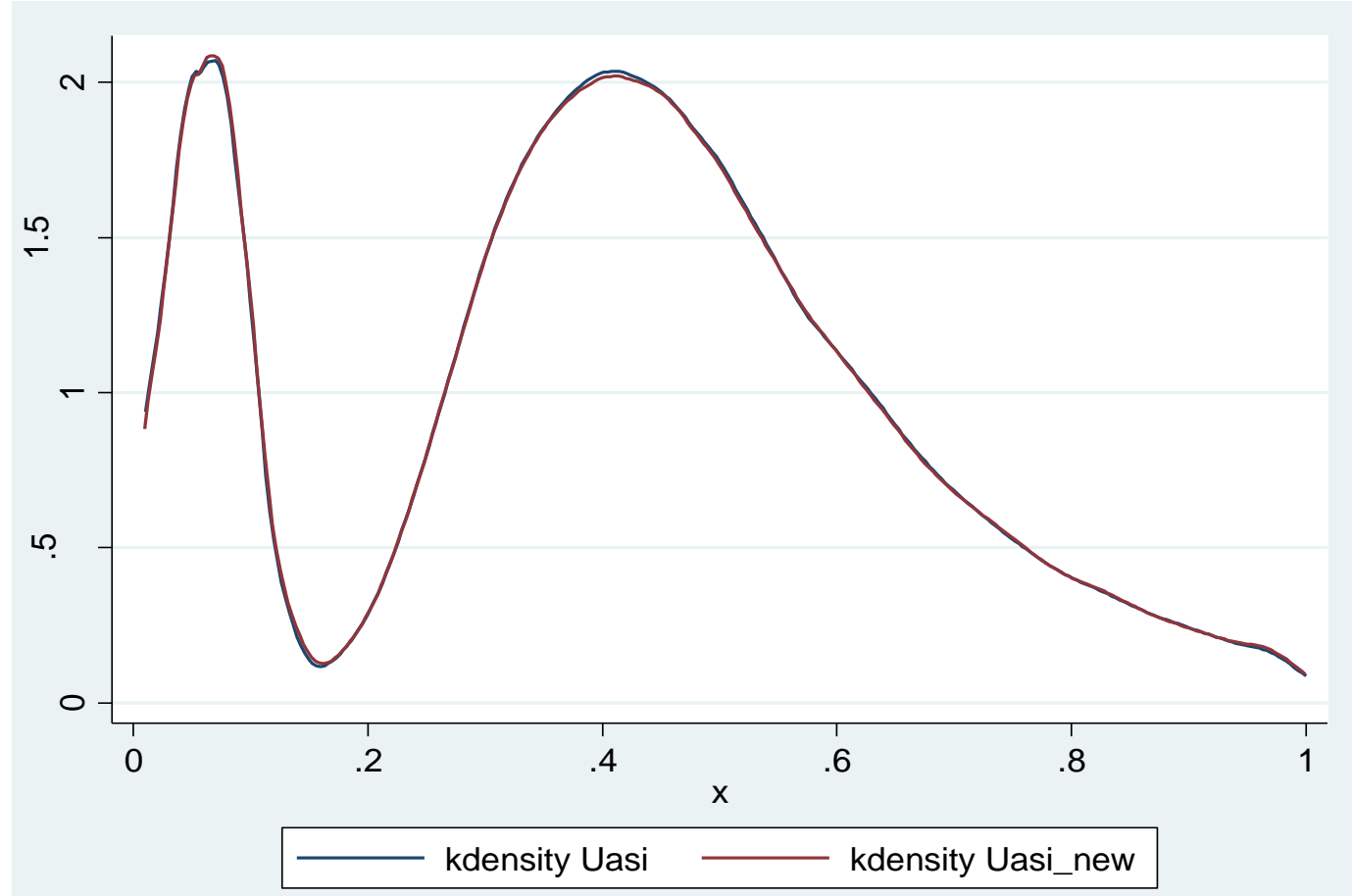

Note: kdensity Uasi and Unsso are efficiency distributions for formal and informal firms respectively, for the pooled sample; kdensity Uasi_new and Unsso_new are for year-year selection. 


\title{
NOTES
}

\begin{abstract}
${ }^{1}$ The contribution of informal economy to GDP in Africa is as high as 59 per cent in Zimbabwe to 28.4 per cent in South Africa. The figures for Asia are 53 per cent for Thailand and 11.3 per cent for Japan. The contribution is highest in case of Georgia - 67.3 per cent (Schneider 2002).

2 De Vries et al. (2012) find evidence of increasing dualism in the Indian manufacturing sector, using employment survey data rather than the firm-level data we use in this paper in the post-1993 period, though they do not explicitly test for the effect of reforms on manufacturing dualism.
\end{abstract}

${ }^{3}$ A firm is classified as being in the small-scale sector and therefore, within the ambit of reservation policy, if its investment in fixed assets in plant and machinery did not exceed a certain limit, and the limit was frequently changed over time. Note that the classification of a firm for the purpose of deciding whether it should fall under the coverage of reservation policy is by the size of the firm's capital stock, and not by the size of the firm's work-force. Therefore, it is possible for the firm to be classified as 'small' under the reservation policy definition as well being a part of the formal sector, if the size of its workforce exceeded 10 workers (if the firm used electricity, and 20 workers, if not).

${ }^{4}$ In contrast, there were less significant reforms in factor markets that manufacturing firms operate in, such as reforms in land, labour and credit markets (Joshi 2010).

${ }^{5}$ Chari (2011) estimates that the de-licensing reform led to an aggregate productivity improvement of 22 per cent in the formal manufacturing sector, three-fourths of which can be attributed to the relaxation of entry constraints.

${ }^{6}$ For an early application of SFA to the estimation of firm efficiency in developing countries, see Taymaz and Saatci (1997).

${ }^{7}$ The method proposed by Heckman (1976) is the conventional one used in the literature to address the selection bias, which, according to Greene (2006), is inappropriate for non-linear models such as Probit and Tobit.

${ }^{8}$ Correspondingly, we re-estimate the probit selection equation for informal firms, where the adoption decision is to be in the informal sector. Once decided/selected, we estimate stochastic frontier estimates for only those firms that decide to be in the informal sector.

${ }^{9}$ Poor electricity provisions, as captured by transmission and distribution losses, have been shown to be a significant impediment to private investment for developing countries (World Bank 2005).

${ }^{10}$ Estimating the selection equation for the pooled firm-level data implies that we are assuming that the effects of labour laws, priority sector lending and T\&D losses on the firm's formalization decision is the same across years. We also estimated selection equations year by year and found no significant change in our results, indicating that the effect of these variables on the firm's location choice is uniform over time (the results are available on request). This is also evident from Figures A1 and A2 in the Appendix, which shows that the efficiency estimates from the selection equations when applied on pooled and year-by-year data respectively are almost identical.

${ }^{11}$ A limitation of our study is that we do not have unit level data on the informal manufacturing sector before 1989-90, which means that we cannot examine the effects of the reforms of the mid 1980s on efficiency differentials between formal and informal firms in this period.

${ }^{12}$ The two terms 'informal sector' and 'unorganized sector' are used interchangeably in the Indian context.

${ }^{13}$ For instance, the $62^{\text {nd }}$ round of NSSO survey conducted in 2005-2006 covered the whole of the Indian Union except (i) Leh and Kargil districts of Jammu \& Kashmir, (ii) interior village of Nagaland situated beyond five kilometres of bus route and (iii) villages of Andaman and Nicobar Islands which remain inaccessible throughout the year. A stratified sampling design was adopted for selection of the first stage units (FSUs). The FSUs were villages in rural areas and Urban Frame Survey (UFS) blocks in urban areas. A total of 9,923 FSUs consisting of 
4,798 villages and 5,125 urban blocks were surveyed. The ultimate stage units (USUs) for the survey were enterprises. The method of circular sampling has been employed for selecting the USUs from the corresponding frame in the FSU. A total of 80,637 enterprises (Rural: 42,050 and Urban: 38,587) were surveyed all over India. A detailed note on the sample design and estimation procedure followed in the $62^{\text {nd }}$ survey is given in the Appendix B of the survey report (NSSO 2007).

${ }^{14}$ It should be noted that while the ASI data are available at the plant level, the NSS provides firm level data and not plant level data. As informal firms by their very nature are single plant establishments, we are, in essence, comparing plant-level estimates for the formal and the informal sectors.

${ }^{15}$ Besley and Burgess (2004) have coded each state amendment to labour laws as neutral, pro-worker or proemployer for the period 1947-1997. We extended the Besley-Burgess variable till 2005 and then normalized it between 0 and 1 such that the more pro-employer labour law amendments in a state would result in higher value for that state.

${ }^{16} \mathrm{We}$ have mentioned in Section II that trade reforms also included major roll-backs and eventual withdrawal of import quotas. However, we do not include import quotas in our measure of trade reforms as we do not have industry data on quotas. Moreover, most of the quotas were dismantled in 1991, while tariff reforms occurred all through the 1990s and early 2000s.

${ }^{17}$ One potential concern about the inclusion of LABOUR LAWS and $T \& D$ LOSSES in our first stage regressions is that these two variables may not meet the exclusion criterion if they affect firm efficiency in the third stage regressions. For example, pro-worker labour regulation and disruptions in electricity supply in a particular state may constrain the productivity of formal firms in that state. It should be noted, however, that the effect of these two variables should only be on formal firms, which by definition are required to adhere to labour regulations and use electricity. In that case, the inclusion of these variables in the third stage to explain the efficiency of both categories of firms will yield biased results. Also, both the variation in labour laws and electricity disruption has been mostly across states in the period of our study (1989-2005) and not over time, while the third stage estimations examine the effect of economic reforms on firm performance over time. As a robustness check, we included LABOUR LAWS and T\&D LOSSES in our third stage estimation, and did not find T\&D LOSSES to be significantly different from zero, though LABOUR LAWS seem to have some impact on formal sector firms in some estimates. More importantly, the signs and significance of our key explanatory variables, FORMAL and REFORM, and their interaction, did not change.

\footnotetext{
${ }^{18} \mathrm{We}$ also used the price of electricity as an alternative proxy for the quality of electricity and found no change in our results.

${ }^{19}$ We also used weighted tariff instead of simple tariff as a measure of trade reforms. Our results did not change, indicating the robustness of the results to different measures of tariffs.

${ }^{20} \mathrm{We}$ also included de-licensing, de-reservation and tariff reform separately in our industry by industry first stage regressions, and found that they were insignificant in several of the industries.

${ }^{21}$ It should be noted that the potential endogeneity of the FORMAL variable is addressed by the three stage estimation method that we have used, and the use of the selection equation in the first stage to address the endogeneity in the firm's decision whether to locate in the formal or informal sector.
} 